\title{
Combining single and complex indices of pollution with grain size trend analysis of surficial sediments in Edremit Gulf, western Turkey.
}

Muhammet Duman ( $\nabla$ muhammet.duman@deu.edu.tr)

Dokuz Eylul Universiy, Institute of Marine Science and Technology https://orcid.org/0000-0002-4771-9675

Filiz Kucuksezgin

Dokuz Eylul Universitesi

Atilla Hüsnü Eronat

Dokuz Eylul Universitesi

Ezgi Talas

Dokuz Eylul Universitesi

Tarık İlhan

Dokuz Eylul Universitesi

Şenol Aydın

Turkish Naval Forces: Office of Navigation

\section{Research Article}

Keywords: Heavy metals, Recent sediments, Spatial distribution map, Pollution index, Complex indices of pollution, Grain size trend analysis (GSTA)

Posted Date: August 24th, 2021

DOI: https://doi.org/10.21203/rs.3.rs-784098/v1

License: (c) (i) This work is licensed under a Creative Commons Attribution 4.0 International License. Read Full License

Version of Record: A version of this preprint was published at Environmental Science and Pollution Research on March 23rd, 2022. See the published version at https://doi.org/10.1007/s11356-022-19355-z. 


\section{Abstract}

Pollution risk assessment of heavy metals $(\mathrm{Pb}, \mathrm{Cr}, \mathrm{Cu}, \mathrm{Ni}, \mathrm{Zn}, \mathrm{As})$ in sediment samples from 68 locations in the Gulf of Edremit, western Turkey, was performed using single and complex indices of pollution assessment approaches. The pollution indices used in the sediment analyses included pollution load index(PLI), contamination factor(CF), contamination degree $\left(\mathrm{C}_{\text {deg }}\right)$ for individual metals, geoaccumulation index (Igeo), enrichment factors(EF), toxic risk index(TRI), modified pollution index (MPI), frequency of adverse biological effects (TEL-PEL), percent incidence of biological effects (ERL-ERM), and total risk quotients

$\left(\mathrm{Q}_{\mathrm{TEL}}-\mathrm{Q}_{\mathrm{PEL}}\right)$. Results indicated a low degree of contamination for the entire surveyed area except moderate contamination factor for arsenic using single indices. Enrichment factors and geoaccumulation indices indicated moderate to significant enrichment and uncontaminated to moderately contaminated both for arsenic(As) and lead(Pb), respectively. According to the results of ecological risk assessment based on TELs and PELs, the adverse biological effects of heavy metals on aquatic organisms; are for As, $\mathrm{Cr}$, Ni frequently, $\mathrm{Cu}$ and $\mathrm{Pb}$ occasionally and $\mathrm{Zn}$ rare. The TRI values displayed low to considerably toxic risk for the entire Gulf and calculated TRI results showed that arsenic accounted for most of the entire sediment toxicity. Transport patterns of sediment grain size trend analyses were correlated with the results of pollution assessment models. Transport trends are compatible with the sources of lithogenic, anthropogenic, mining activities and wastewater treatment/geothermal originated arsenic.

\section{Introduction}

Metal pollution in coastal areas, estuaries and bays has recently received increasing attention since it could be unhealthy for humans and living organisms in the marine ecosystem. The degrading impact of rapid urbanization and industrialization on the quality of water resources has emerged as a matter of concern across the globe (Khan et al., 2021). A significant number of industrial wastes containing metals have caused substantial and fast environmental degradation, especially in coastal environments. Accordingly, the ecosystem may possibly be spoiled and threaten all types of organisms including human beings. Metals accumulate in sediments and can be adsorbed via benthic organisms or/and released into the water, causing deterioration of water quality. Sediments are sensitive indicators for monitoring pollutants in aquatic environments and are typically regarded as the ultimate sink for heavy metals discharged into these environments (Zhang et al., 2014; Khan et al., 2017; Jeong et al., 2021).

Several studies regarding metal contamination and its connected environmental problems have been conducted in the marine coastal areas and rivers around the world (Feng et al. 2004; Hyun et al. 2007; Niencheski et al. 2014; Wu et al. 2014; Aguilar Pesantes et al. 2019). Recent studies have shown that pollutants such as organic pollutants, heavy metals, pathogens, nitrogen and phosphorus in sediments are ubiquitous and cause health risks to human and macrobenthos (Passos et al. 2010; Tornero et al. 2014; Saleem et al. 2015). The persistency and toxicity of inorganic pollutants in the marine environment, the index-based pollution approach for categorizing of sediments become very crucial. Distribution of metals in the sediment supply knowledge about their sources (Chen et al. 2015; Pejman et al. 2015; Sołek-Podwika et al. 2016). Historical human activities could be reflected sediment enrichment with metals could give explanations about historical human activities (Tang et al. 2015; Mazurek et al. 2017).

The influence of the pollutants on the concentration of metals in the sediments requires the convenient evaluation as well as detection of their ecological risk (Hakanson, 1980; Zhong et al. 2010; Gao and Chen, 2012; Baran et al. 2018). Sediment quality guidelines and background levels are extensively utilized in ecological risk evaluations to assign metal pollution in the marine environment (Xu et al., 2015). The effective evaluation of sediment pollution with heavy metals are performed using several pollution indices such as enrichment factors (EF), geoaccumulation index ( $\left.\mathrm{I}_{\text {geo }}\right)$, contamination factor (CF), degree of contamination (Cdeg), modified degree of contamination ( $\mathrm{mCd}$ ), modified pollution index (MPI), toxic risk index (TRI). The indices assist to find out whether the accumulation of metals was due to anthropogenic activities or natural resources (Sutherland, 2000; Caeiro et al. 2005; Elias and Gbadegesin, 2011).

Although several studies on concentrations of heavy metals and ecological risk assessment based on concentrations of trace elements along the Turkish coasts. There has yet not been an extensive research concerned with the metal contamination 
levels and ecological risk assessment in Edremit Gulf. The current study investigates distribution of metal concentrations, to assess possible enrichment, to evaluate metal pollution of the surface sediments using several indices, to compare to the results from other studies around the world, to identify possible sources and ecological risks of metals using established sediment quality guideline in Edremit Gulf.

\section{Material And Methods}

Study area

The area of study which is the northernmost Gulf on the Aegean coast of Turkey and located between the Ida Mountain and Madra Mountains. Edremit Gulf, separates the Anatolian Peninsula and Lesbos Island (Fig. 1). There are many settlements such as Küçükkuyu, Altınoluk, Akçay, Burhaniye, Gömeç and Ayvalık around the bay and tourism activities increase especially in the summer period in this area. Edremit and surrounding areas are famous for their olive cultivation and oil production as well as ore deposits in Turkey. Agricultural activities (especially fruit and vegetable growing) and fishery are of great importance in this area. There are several active metal mines (Yiğit, 2012) and several studies involving ore deposits around the investigation area have been conducted (Çolakoğlu, 2000; Yiğit, 2006; Yılmaz, 2007; Yiğit, 2009; Oyman, 2010; Akiska et al. 2013; Somay, 2016).

\section{Sampling and measurement}

The sediments were taken using a Box-corer from a total of 68 sampling station (Fig. 1) during the surveys of R/V Dokuz Eylül 3 under the framework of a scientific project in the autumn of 2017 (TUBITAK-115Y180, 2018). The samples were transported in the ice bags and kept in a deep freeze until the drying step. Then sediments were dried in freeze-dryer (LABCONCO), homogenized and were sieved through $63 \mu \mathrm{m}$ for grain size correction. 3A total of 31 element concentrations were measured in the digested phase of samples using ICP-MS (Analytical Labs ACME, Vancouver, Canada). Reference sediment sample (STD OREAS25A-4A and STD OREAS45E) was utilized as quality control of data for the analytical method.

The total carbonate and organic carbon levels were determined in the sediments by adopting the standard methods (Loring and Rantala, 1992). The analysis of total organic carbon was performed by sulfochromic oxidation analytical procedure in spectrophotometry and the accuracy of this method is given as $\pm 0.017 \%$ organic substance. The amount total carbonate level was measured using a gasometric method, that was adopted from Scheibler gasometer (Müller, 1967).

The particle size analysis was used to detect gravel and sand fractions which are bigger than $63 \mu \mathrm{m}$. The fine grained fractions (clay and silt), which are smaller than $63 \mu \mathrm{m}$, were found by hydrometer procedure. The grain size classification of the sediments depends on the relative percentages of clay $(<0.002 \mathrm{~mm})$, silt $(0.002-0.063 \mathrm{~mm})$, sand $(0.063-2 \mathrm{~mm})$ and coarse sand-gravel (> $2 \mathrm{~mm})$. The sediment textural classes are examined using the procedure of Folk (1974).

Pollution indices

Metals can accumulate in ecosystems as a result of natural and/or anthropogenic effects. The accumulation of pollutants in marine environments occurs predominantly within the sediment in depositional areas on seabed. Many methods are used to determine anthropogenic, environmental and other effects. Evaluating the quality of sediment relies on a number of substantial indices suggested by investigators. Several of these indices were utilized in the current study to assess the degree of metal contamination in sediment. To establish the sediment pollution rate resulting from the investigated metals, it is necessary to compare the metals contents with unpolluted reference values. Contamination in sediment samples taken from the marine environment of Edremit Gulf was evaluated methods as EF, Igeo, Cf, Cdeg, Mcd, MPI. The calculation formulae for used indices are summarized in Tables S1 and S2 includes the classes of pollution.

\section{Sediment quality parameters}

To determine the potential toxicity of sediments in aquatic ecosystems, sediment quality criteria developed by Florida Environmental Protection Agency (FDEP) and National Oceanic and Atmospheric Administration (NOAA), particularly the TEL 
and PEL, and the ERL and ERM (Table 1), are used, respectively (Long et al. 1998). Three ranges of element concentrations were used to classify biological adverse effects for the TEL-PEL and ERL-ERM: First, the lowest range of levels, within which adverse effects are rarely detected (below TEL and ERL); Second, the possible effects range, between the TEL to PEL and ERL to ERM, within which adverse effects are occasionally monitored; and third, the probable effects range above PEL and ERM, within which adverse biological effects are frequently observed (Long et al. 1995; MacDonald et al. 2000) (Table S3).

Risk assessment and toxicity prediction

One of the two methods utilized to evaluate the toxic risks of sediments polluted with heavy metals is based on TEL and PELs. In this method based on TEL and PELs, the total risk segments of heavy metals, $Q_{T E L}$ and $Q_{P E L}$, are expressed by the following formulas.
$\mathbf{Q}_{T E L}=\sum_{i=1}^{n} \frac{C}{T E L}$
(7) (Zhang et al. 2017)
$\mathbf{Q}_{P E L}=\sum_{i=1}^{n} \frac{C}{P E L}$
(8) (Zhang et al. 2017)

where, $C$ is the content of heavy metal measured in sediment. If $Q_{P E L}>1$ sediment is defined as highly "toxic". If $Q_{P E L} \leq 1 \leq Q_{T E L}$ the risk is variable and if the $\mathrm{Q}_{\mathrm{TEL}}$ is $<1$, the heavy metal content in the sediment is not risky for benthic organisms. The sediments were classified as "non-toxic" (toxicity < 10\%), "uncertain" ( $10 \% \leq$ toxicity $\leq 30 \%)$ and "toxic" (toxicity $>30 \%)$, according to the results of toxicity tests (Zhang et al. 2017).

Toxic risk index (TRI) was utilized to evaluate the toxic risk based on both the TEL and PEL effects of trace metals. The TRI of a certain metal was calculated using the following equation:

$\operatorname{TRI}_{i}=\sqrt{\frac{\left(\left(\frac{c_{i}}{T E L}\right)^{2}+\left(\frac{c_{i}}{P E L}\right)^{2}\right)}{2}}$

(9) (Zhang et al. 2016)

where, $\mathbf{C}_{\mathbf{i}}$ is metal concentration $\mathrm{i}\left(\mathrm{mgkg}^{-1}\right)$ in the sediment sample, and $\mathbf{C}_{\mathrm{iTEL}}$ and $\mathrm{Ci}_{\mathrm{PEL}}$ are the TEL and PEL of metal i(mgkg $\left.{ }^{-1}\right)$, respectively. The integrated toxic risk index for various metals in one sediment sample could be calculated by Eq. (10).
$\operatorname{TRI}=\sum_{i=1}^{n} \operatorname{TRI}_{i}$
(10) (Zhang et al. 2016)

Toxic risks were categorized into five categories: (1) TRI $\leq 5$, no toxic risk; (2) TRI 5-10, low toxic risk; (3) TRI 10-15, moderate toxic risk; (4) TRI 15-20, considerable toxic risk; and (5) TRI $\geq 20$, very high toxic risk (Zhang et al. 2016).

Multivariate analysis

Since PCA and CA are the most extensive multivariate statistical methods used in marine investigations (Shen et al. 2019), to determine the correlation between metals in marine sediments and pollution sources, cluster analysis (CA) and principal component analysis (PCA) were conducted using the statistics software package SPSS (Windows, version 25.0). PCA was used to decrease the size of data and investigate highly associated heavy metal elements into independent factors. Cluster analysis (CA) sorted heavy metals into different classes, and the classes required for clustering were unknown.

Grain size trend analysis (GSTA)

Sediment trend size analyses is a Fortran program as developed by Gao and Collins (1992) and was used to describe sediment transport patterns and deposition where the grain-size trends within a grid of surficial sediments are converted into a residual pattern displaying net sediment transport pathways. These vectors define the directions of sediment transport, even though their magnitudes are meaningless. Within the scope of this study, QGIS 2.8-GiSedTrend Ver. 2.5 developed program (Poizot 
and Mear, 2010) based on the Fortran software GSTA (Grain size trend analysis) adapted by Gao (1996) to model sediment transport and deposition was used and sediment transport vectors were defined for the entire study area.

The grain-size parameters of surface sediments have been used to determine their transport directions over the last three decades. This method is based on producing changes in the grain size parameters (size, sorting and skewness) in the direction of transport during the sedimentation process. These trends have been properly used to establish sediment distribution patterns in the gulfs and shallow coastal areas (Gao et al. 1994; Gao, 1996; Chang et al. 2001; Duman et al. 2004; Duman et al. 2006; Héquette et al. 2008; Poizot et al. 2008; Papatheodorou et al. 2012; McLaren and Tear, 2014; Duc et al. 2016).

\section{Results And Discussion}

Sediment type, carbonate and organic carbon

Grain size composition of recent sediments in Edremit Gulf display high sand contents as (mean) $45 \%$ followed by silt and clay with a median value of $43 \%$ and $10 \%$, respectively (Table 1 ). Their composition is mainly silty and sandy, with varying rates of coarse and fine, thus they include the entire range from mud to silt, sandy silt, silty sand and sand (Fig. 2a). Considering the spatial distribution of the sand-sized material, except for Ayvalık port and Gömeç coastal areas, the southern part of Edremit Gulf and the northwest coastal zone around Müsellim Passage where it is connected with the open Aegean Sea has a high concentration of over $50 \%$ (Fig. 2b). Silt contents (> 50\%) prevailing in the zone between the southern shore of Edremit inner gulf and Assos basin, high values (> 75\%) are observed in Assos basin and Altınoluk regions (Fig. 2c). While clay, the finest sedimentary unit with a maximum content of $35 \%$, shows distribution in deeper areas of the Assos basin and southern offshore section of Küçükkuyu, it also has high values in coastal areas of Ayvalık, Gömeç and Ören (Fig. 2d).

Fine-grained sediments (silt-clay) show higher contents in deeper sections of Edremit Gulf with exceptions on south-eastern coastal areas between Ayvalık and Burhaniye. Usually, grain-size distribution trends were expressed by depth variations, with finer particles being found in the deeper sections (Assos basin and offshore Küçükkuyu) and coarser sediments in shallow areas (northern and southern entrance of Gulf). Coarse grained sediments are widespread on the shelf area, which is normally shallower than 50m, at the southern and northern entrances (around Alibey island and Musellim passage) where Edremit Gulf is connected with the open Aegean Sea. This configuration can be evaluated as a result of bottom water movements developed under the effect of cyclonic water circulation (Giamali et al. 2020), which is characteristics of the northern Aegean Sea.

Organic carbon $\left(\mathrm{C}_{\text {org }}\right)$ content show high variability, in between $0.37 \%$ and $3.44 \%$, and mean value of $1.67 \%$ (Table 1 ); the highest organic carbon values (up to $3.0 \%$ ) are detected both coastal areas of southern and northern exits and additionally the eastern part of the inner Gulf (Fig. 2e). While the higher contents of the $\mathrm{C}_{\text {org }}$ is a factor of limited circulation in Ayvalık Bay, other areas of local maxima possibly related to waste-water treatment plants (WWTP) located around the Edremit Gulf. Potential effects of these locations on $\mathrm{C}_{\text {org }}$, carbonate and trace element contents (eg $\mathrm{As}, \mathrm{Cr}, \mathrm{Cu}, \mathrm{Ni}, \mathrm{Pb}, \mathrm{Zn}$ ) will be discussed in the following sections.

According to microscobic observations Edremit Gulf sediments contain autochtonous biogenic carbonates, such as foraminifera, bivalves, gastropod shells, and their fragments. Total carbonate content of Edremit Gulf sediments showed high variability, with a maximum level of $65 \%$, minimum level of $7 \%$ and mean value of $27 \%$ (Table 1) that indicates that on average of more than one-fifth of the sediment samples consist of biogenic particles. Carbonate distribution (Fig. 2f) shows different trends in comparison to $\mathrm{C}_{\text {org }}$, with maxima $(>50 \%)$ in southern entrance of the Edremit Gulf around Alibey island and Northern exit of the Gulf.

Contents and areal distribution of trace elements

Investigated heavy metal levels of 68 surface sediments of Edremit Gulf presented in Table 1. The overall results demonstrated that the contents of trace elements in recent sediments were in the range of Al: $1.8-8.17 \%$, Fe: $1.24-4.86 \%$, As: $16-63 \mathrm{mg} / \mathrm{kg}$, Cr: 26-200 mg/kg, Cu: 6.4-51.5 mg/kg, Ni: 14.6-137 mg/kg, Pb: 16.8-63.7 mg/kg, Zn: 31-123 mg/kg. The comparison between metals concentrations in the current study and the most recently published data at marine environments in 
Mediterranean Sea are given in Table 2. In the limited number of studies in which results on As concentrations were given, the mean As values were lower than the values measured in this study (Martínez-Guijarro et al. 2019; Karageorgis et al. 2020, Radomirović et al. 2021). While the average values of $\mathrm{Cr}, \mathrm{Cu}$ and $\mathrm{Ni}$ from other metal concentrations are lower than Christophoridis et al. (2019), Karageorgis et al. (2020), Radomirović et al. (2021) and higher from Martínez-Guijarro et al. (2019), Karditsa et al. (2014), Abbasi and Mirekhtiary (2020), Ben Amor et al. (2019), Balkıs et al. (2020). The average values of $\mathrm{Pb}$ and $\mathrm{Zn}$ are only higher than Koukounari et al. (2020), Martínez-Guijarro et al. (2019), Abbasi and Mirekhtiary (2020) and lower than the others listed in Table 2. Overall, the metal concentrations studied in this study showed significant fluctuations compared to some of the most recent studies on coastal areas mentioned in Table 2. When the mean concentrations of heavy metals in the study region of Edremit Gulf are examined, Cr has been the highest value with $86.2 \mathrm{mg} / \mathrm{kg}$ followed by $\mathrm{Zn}$ (72.3 $\mathrm{mg} / \mathrm{kg}), \mathrm{Ni}(55.2 \mathrm{mg} / \mathrm{kg}), \mathrm{Pb}(35.9 \mathrm{mg} / \mathrm{kg})$, As (29.2 mg/kg), Cu (22.7 mg/kg) and Al (6.15\%), Fe (3.21\%). Based on Fig. S1, which shows the spatial distribution of trace elements in the sediments from the Edremit Gulf, the distribution patterns of trace element concentrations of $\mathrm{As}, \mathrm{Cr}$, and $\mathrm{Ni}$ tend to decrease from the same coastal sources, while $\mathrm{Cu}, \mathrm{Pb}, \mathrm{Zn}$ and $\mathrm{Al}$ and $\mathrm{Fe}$ showed commonly deep basin concentrations. In the eastern half of the Gulf, both northern and southern side, the levels of metals were relatively high, showing that discharges of small rivers and streams were the possible pollution sources. Contents of some trace elements, as As in some areas have four times higher than their background levels. Highest metal (Cr, Zn, Ni) concentrations distributed mainly eastern half of the north side of the Gulf and central part of the southern shore around Gömeç. While high As contents are mainly focused on the coastal regions of southern side, in the north they spread only at the center of Küçükköy area and decrease relatively without showing any depocenter in the offshore part of the Gulf. The distribution model of the center with high As values are predominantly in accordance with the local wastewater treatment plant discharge locations.

Unlike other metals, $\mathrm{Cu}, \mathrm{Pb}$ and $\mathrm{Zn}$, which show approximately the same distribution patterns, whose common features are an increase in concentration from the coast to the open sea have high concentrations above the reference values in shallow and deep depocenters. All these element contents tend to decrease in the offshore direction where lower concentrations were observed than the accumulations on the eastern coastal areas. The Al and Fe values, which showed concentrations close to reference values, contain high values in natural depocenters shaped in accordance with the bottom morphology of the Gulf (Fig. S1). Since the coastal areas with open sea connections in the west of the Gulf are exposed to more sediment movement compared to the inner parts of the bay, they have mainly erosional/transport rather than depositional areas. The average concentrations of heavy metal contents of the inner coastal canters that depositional trends more active are in the order $\mathrm{Cr}>\mathrm{Zn}$ $>\mathrm{Ni}>\mathrm{Pb}>\mathrm{As}>\mathrm{Cu}$. The only study done on the basis of limited sediment samples across the Edremit Gulf belongs to Meriç et al. (2012). According to this study, as a result of $\mathrm{Co}, \mathrm{Cu}, \mathrm{Cr}, \mathrm{Mn}, \mathrm{Ni}, \mathrm{Pb}, \mathrm{Fe}$ and Al elements, it was concluded that the metal enrichment in Edremit Gulf originated from the metal ores located in the northwest Aegean Region.

Relationship between element concentrations and sediment grain size

Organic matter and sediment grain size are the most important parameters of sediments that affect the concentration of metals (Giordano et al. 1999; Cai et al. 2011). Fine particles absorb soluble metals in seawater and transport them to the surface sediments of the seafloor. In general, the levels of heavy metals increase with decreasing grain size (Förstner and Wittmann, 1983) and the fine fraction $(<63 \mu \mathrm{m})$ is generally preferred in environmental research as it has the ability to bind elements through complex adsorption and/or absorption mechanisms (Tessier et al. 1984). Among all metals examined in this study, Al $(r=0.569, P<0.001), \mathrm{Cr}(r=0.515, \mathrm{P}<0.001), \mathrm{Cu}(r=0.774, \mathrm{P}<0.001), \mathrm{Ni}(r=0.673, \mathrm{P}<0.001), \mathrm{Pb}(\mathrm{r}=0.534, \mathrm{P}<0.001)$. $\mathrm{Zn}(r=0.783, \mathrm{P}<0.001)$ showed an extremely positive correlation with fine material consisting of silt and clay (Table S4). In contrast, the content of As $(r=0.232, p<0.10)$, which correlates poorly with the fine material, is also not associated with the coarse sized material. This indicates that grain size is not the predominant factor controlling the As distribution in the surficial sediments of the Gulf and probably a different source of As from all other metals. The TOC levels in the sediments varied from $0.37-3.44 \%$. Heavy metals tend to be absorbed by biological matters (lanni et al. 2010), so the organic matter is a good metal filter (Wasserman et al. 1998; Weiping et al. 2014) and plays an important role in metal reserves in sediments. Edremit Gulf sediment TOC and heavy metal data show no such correlation, except for $\mathrm{Cu}$ and $\mathrm{Pb}$, which are positively correlated with low values (Table S4) and therefore predominantly indicate anthropogenic and/or lithogenic source other than biological source. 
Trace element interrelations and source identification

In Pearson's correlation coefficients (Table S4), a positive and significant correlation was observed with the fine material, lithogenic $\mathrm{Al}$ and $\mathrm{Fe}$ and other elements except As, while it was negatively correlated with $\mathrm{CaCO}_{3}$, which was positively correlated with coarse grained material and represented biogenic carbonates (also see Figs. $2 b$ and $2 d$ ). All trace elements except As are distinctly related to Al and Fe suggesting that their common origin is due to lithogenic or similar transport patterns. Various anthropogenic effects on the region were determined by evaluating the relationships between trace elements, organic carbon, carbonate and grain size. For this purpose, by grouping variables with common geochemical behaviour. Principal Component Analysis (PCA), in which the varimax rotation is applied with Kaiser Normalization, has been performed to the existing data to define the heavy metal sources in Edemit Gulf surface sediments. By extracting the eigen values and eigen vectors from the correlation matrix, the number of important factors and the percentage of variance described by each were calculated.

Table S5 demonstrates the results of varimax transformed factor values and Eigen values and communalities. The results showed that there are five Eigen values higher than 1 and these five factors cover $83 \%$ of the total variance. The first factor accounts for $51.5 \%$ of the total variance and concentrates strongly on $\mathrm{Ni}, \mathrm{Cr}, \mathrm{Co}(>0.7)$ and moderately to low for $\mathrm{Fe}, \mathrm{V}, \mathrm{Al}, \mathrm{Mn}$ and $\mathrm{Cu}$ which are loaded $>0.4$. Factor 1 , which is partly positively loaded lithogenic elements associated with fine-grained soil including silt (0.6) and clay (0.2) indicates an anthropogenic-lithogenic origin with high $\mathrm{Cr}$ and $\mathrm{Ni}$ values predominantly from mining waste. As can be seen from Fig. 3a, it points to the important input originating from the northern shores of the bay and affecting a large section of the Gulf. Factor 2 constitutes $12.9 \%$ of the total variance, with $\mathrm{Sn}, \mathrm{Zn}, \mathrm{Pb}$, Cu scores above $>0.7$ and secondarily with relatively high values of Silt and clay dominated by $\mathrm{Al}, \mathrm{Fe}$ and $\mathrm{V}(>0.4)$. Considering the relevant metals and the spatial distribution model given in Fig. 3b, together with the partial lithogenic source, it indicates an anthropogenic pollution associated with the Ayvalık cantered maritime traffic. Traffic could be considered a notable source of $\mathrm{Cu}, \mathrm{Ni}, \mathrm{Pb}, \mathrm{Sn}$ and $\mathrm{Zn}$ pollution, particularly since there are urban areas of around the gulf. Moreover, runoff is an important source of heavy metals in the marine surrounding, while contents of the heavy metals from transporting emissions and ships are correlated with the density of traffic (Christophoridis et al. 2019). Factor 3 is loaded primarily by $\mathrm{Ba}$, Al, and $\mathrm{Nb}>0.7$, as well as moderately by $\mathrm{Rb}, \mathrm{V}$, $\mathrm{Pb}$ and $\mathrm{Fe}(0.4)$, making up $9.5 \%$ of the total variance and representing the lithogenic factor with high Al value. Low (>0.4) level loadings (Al, Fe, ) within the first two factors indicate the partial lithological effect within the respective group. In total, these three factors account for $73.9 \%$ of the total variance and are shown in a three-dimensional space (Fig. 3). As can be seen from Fig. 3 (top left), the first three factors were found to overlap locally in regions around Al and Fe. This combination consisting of the contributions of Al and Fe (Table S5), which are among the basic parameters of all three factors, indicates that the main factor in Edremit Gulf is predominantly lithogenic. The main element group of first three factors includes primary heavy metals (Ni, $\mathrm{Cr}, \mathrm{Co}, \mathrm{Cu}, \mathrm{Pb}$ and $\mathrm{Zn}$ ) and nutrients (organic carbon), which are normally thought as the anthropogenic pollutants mostly related to the discharge of agricultural, industrial wastes and untreated domestic sewage and also marine and land traffic activities (Qi et al. 2010; Lu et al. 2010). Anthropogenic sources of heavy metals are indicated in the world wide marine areas in numerous former studies (Abbas et al. 2016; Birch, 2017; Martínez-Guijarro et al. 2019; Karageorgis et al. 2020).

Factor 4 accounts for $5.3 \%$ of the total variance with high contribution of As and $\mathrm{Sb}$ and low contribution of $\mathrm{Mn}, \mathrm{Co}, \mathrm{Ni}, \mathrm{Fe}, \mathrm{Cr}$, $\mathrm{Cu}$, respectively. In the spatial distribution model given in Fig. $3 \mathrm{~d}$, high values are mainly concentrated in the locations where wastewater treatment systems and geothermal resources are located, and the relevant positive metal charges indicate the wastewater discharge -geothermal factor in this study. As with high loading (0.9), which is the highest representative of factor 4 , was suggested to be associated with geothermal waters in Somay (2016). Factor 5, which accounts for the lowest $3.9 \%$ of the total variance, is strongly correlated with Mo, S, organic carbon, almost all of which have high loading values (>0.68). This factor has been defined as the "organic matter sulfurization" factor due to the following environmental characteristics (Fig. 3e). According to Qi et al. (2010) S has negative correlations with anthropogenic and lithogenic components and positive correlations with biogenic elements, showing a marine source instead of terrigenous origin. High OC, high Mo and low As conditions demonstrate possible circumstances of sulfurized organic material in sediments. High Mo levels point out that reactive iron was limiting factor, preventing As capture (Tribovillard, 2020).

Establishing natural background levels in the study area

Page $7 / 25$ 
Local geochemical background concerns the element content in the sediments without any anthropogenic enrichment, i.e., the element content is supplied by natural sources such as biogenic and terrigenous components. After preliminary trials using three different sediment cores it was found that there is no significant difference in the background levels between the three locations of the Edremit Gulf. To distinguish the pre-industrial deposits in the Gulf, available two 14C dated core data taken from northeastern part of Edremit Gulf were used from Yümün and Önce (2017). In the Edremit Gulf, the sediment accumulation rates were calculated at $0.57 \mathrm{~cm} \mathrm{y}^{-1}$ and $0.75 \mathrm{~cm} \mathrm{y}^{-1}$, thus element contents of deepest core levels (88-150 $\mathrm{cm}$ ) are used as background values. Table 1 displays the pre-industrial values of metals defined as background values for each core locations.

Risk assessment and contamination

The pollution indices are useful tools to assess the sediment contamination. In this study, several relaiable contamination and risk indicators utilized in previous investigations, as well as new indices were used to asses pollution degree and potential ecological risk (Bourliva et al. 2018; Christophoridis et al. 2019). The Enrichment Factor (EF), Geoaccumulation Index (Igeo), Contamination Factor (CF), Modified Pollution Index (MPI) and Toxic Risk Index (TRI) were used. Morover, SQGs along with the QTEL and QPEL were used to estimate the seabed surficial sediment contamination in sampling region.

\section{Enrichment Factor (EF)}

To analyze if the heavy metals in Edremit Gulf surficial sediments were affected by anthropogenic activities, enrichment factors (EFs) based on the earth's crust were computed using Eq. 1 and the results are shown in Fig. 4. Calculated EF values exhibited ranges of 1.3-8.9 for $\mathrm{As}, 0.4-2.7$ for $\mathrm{Cr}, 0.3-1.3$ for $\mathrm{Cu}, 0.3-2.3$ for $\mathrm{Ni}, 1.4-5.1$ for $\mathrm{Pb}$ and $0.6-1.8$ for $\mathrm{Zn}$. The highest $\mathrm{EFs}$ were calculated by As followed by $\mathrm{Pb}$, while average EFs indicated decreasing order of $\mathrm{As}>\mathrm{Pb}>\mathrm{Cr}>\mathrm{Ni}>\mathrm{Zn}>\mathrm{Cu}$ with respective values as 3.1, 2.5, 1.3, 1.1, 1.0 and 0.7. The EF values of all determined heavy metals (except $\mathrm{Cu}$ and $\mathrm{Zn}$ ) are higher than 1.5 that suggesting their anthropogenic source. Alternatively, the $\mathrm{EF}$ values of $\mathrm{As}, \mathrm{Pb}>5$ and $\mathrm{Cr}, \mathrm{Ni}>2$ indicated significant to moderate enrichment respectively. The basic distribution of EF values between stations (a) and within each heavy metal (b) were shown in Fig. 4. While moderate and significant enrichments are observed on $\mathrm{EF}$ values of $\mathrm{As}, \mathrm{Pb}, \mathrm{Cr}$ and $\mathrm{Ni}$, all values for $\mathrm{Cu}$ and $\mathrm{Zn}$ indicate minimal enrichment. When the spatial distribution of EF-As values, which constitute the highest values among all metals studied, is examined, almost all of the southern coastal areas and the central part of the northern coast of around Küçükkuyu demonstrated higher EF values than those in the central part of the Gulf (Fig. 4c). The high EF-As values observed in the northern part where EF-Pb values are minimal, were evaluated as untreated urban sewage and geothermal origin. $\mathrm{EF}$ of $\mathrm{Cr}$ and Ni display generally minimal values except northern coast around Küçükköy and Edremit, which shows moderate enrichments related with mining activity (Fig. 4e, f).

\section{Geoacumulation Index $\left(I_{\text {geo }}\right)$}

The $I_{\text {geo }}$ values of the heavy metals in Edremit Gulf's surficial sediments were computed based on the crust of the earth using Eq. 2 and results are presented in Fig. 5. All analyzed samples displayed negative $\mathrm{I}_{\text {geo }}$ values of $\mathrm{Cu}$ and $\mathrm{Zn}$ and were defined as "non-polluted" regarding these two metals. Calculated I geo values ranged from -0.7 to 1.7 for As, -2.4 to 0.6 for Cr, -3.4 to -0.4 for $\mathrm{Cu},-2.8$ to 0.4 for $\mathrm{Ni},-0.8$ to 1.0 for $\mathrm{Pb},-2.2$ to -0.2 for $\mathrm{Zn}$. The highest $\mathrm{I}_{\text {geo }}$ values were calculated by As followed by $\mathrm{Pb}$, while average $\mathrm{I}_{\text {geo }}$ values indicated decreasing order of $\mathrm{As}>\mathrm{Pb}>\mathrm{Cr}>\mathrm{Ni}>\mathrm{Zn}>\mathrm{Cu}$ with respective values as $0.5,0.2,-0.8,-1.0,-1.1$ and -1.7 , which was parallel to the trend traced in the enrichment factor values. The $\mathrm{I}_{\text {geo }}$ values of $\mathrm{Cu}$ and $\mathrm{Zn}$ and majority of $\mathrm{Cr}$ and $\mathrm{Ni}$ in the Edremit Gulf, which proposed that the sediments are not polluted by anthropogenic origins. The general distribution of $\mathrm{I}_{\text {geo }}$ values between stations (a) and within each heavy metal (b) is shown in Fig. 5. While moderately contamination is observed on $\mathrm{I}_{\text {geo }}$ values of only $\mathrm{As}$, nearly all values for $\mathrm{Pb}$ indicate uncontamination to moderately contamination. While a few uncontaminated to moderately contaminated values are observed in $\mathrm{I}_{\text {geo }}$ values of $\mathrm{Cr}$ and $\mathrm{Ni}$, a significant part of the remaining values consists of uncontaminated as in $\mathrm{Cu}$ and $\mathrm{Zn}$. 
When the spatial distribution of $\mathrm{I}_{\text {geo }}$-As values is examined, which constitute the highest values among all metals studied, almost all of the southern coastal areas and the central part of the northern coast around Küçükkuyu exhibited higher $I_{\text {geo }}$ values than those in the central part of the gulf (Fig. 5c) the same trend as EF values (Fig. 4c). It has been observed that the $\mathrm{I}_{\text {geo }}$ values of the $\mathrm{Pb}$ data throughout the area and the $\mathrm{Cr}$ and Ni values are uncontaminated to moderately contaminated only in a few stations, especially around Küçükkuyu, on the north coast. Except for the high values of $\mathrm{Cr}$ and Ni observed in the limited area around Küçükkuyu, all of the data are uncontaminated (Igeo $<0)$ throughout the bay as well as $\mathrm{Cu}$ and $\mathrm{Zn}(\mathrm{Fig}$. 5d,e,f). As shown in Fig. 5g, both EF and Igeo showed similar results for trace element contamination levels in the sediments of Edremit Gulf. As and $\mathrm{Pb}$ were dominating contamination, $\mathrm{Cr}$ and Ni pollution were also observed in limited coastal regions, proposing that main driving factor for the enrichment of $\mathrm{As}, \mathrm{Pb}, \mathrm{Cr}$ and Ni was anthropogenic origin. Nevertheless, $\mathrm{Cu}$ and $\mathrm{Zn}$ were firstly originated from natural sources like mentioned at recent work of Wang et al. (2020).

\section{Pollution indices}

The calculated contamination factor (Cf) (Eq. 3), pollution load index (PLI), degree of contamination ( $\mathrm{C}_{\text {deg }}$ ) (Eq. 4) and modified degree of contamination ( $\mathrm{mCd}$ ) (Eq. 5) values for heavy metals are given in Table S6. Cf values of the trace elements were found in the order of $\mathrm{As}(1.62)>\mathrm{Pb}(0.99)>\mathrm{Zn}(0.86)>\mathrm{Cr}(0.84)>\mathrm{Cu}(0.82)>\mathrm{Ni}(0.71)$. Between the calculated Cf values only displayed the moderate contamination for arsenic while the rest of the $\mathrm{Cf}$ values exhibited low contamination $\mathrm{for} \mathrm{Pb}, \mathrm{Zn}, \mathrm{Cr}, \mathrm{Cu}$ and Ni. Since the average pollution load index (PLI) was nearly 1 (0.99), which indicated baseline level of pollution for the entire area of investigation. The interpretation of PLI value is defined as polluted (PLI > 1); baseline level of pollution (PLI = 1) and not polluted $(\mathrm{PLI}<1)$ (Liu et al. 2005; Chakravarty and Patgiri, 2009). The degree of contamination $\left(\mathrm{C}_{\mathrm{deg}}\right)$ and $\mathrm{mCd}$ values were calculated as 5.84 and 0.97 respectively. These values correspond Low degree of contamination for $\mathrm{C}_{\text {deg }}$ and Nil to very low contamination for $\mathrm{mCd}$.

Multi elemental pollution indices are beneficial to single element ones, as for instance EF, as they combine the additional impact of multiple pollutants, which are frequently existing in industrialized and urbanized surroundings, in sediment quality evaluations. Among other indices within the study, the Modified Pollution Index (MPI) presented by Brady et al. (2015) has also been utilized. Several researchers tried the MPI in varied sampling regions and deduced that it is more confident than other unidimensional and multidimensional indices. This idea has been lately reported by Karageorgis et al. (2020). It was computed by Eq. 6 and could be thought of as an improvement of the Håkanson's modified degree of contamination index (mCd) (Eq. 5) (Håkanson, 1980) in the sense that a suite of elements is combined to generate a single value, in the way that it uses the $\mathrm{CF}_{\max }$ to develop a weighted average, hence considering the effect of contamination of one element, that otherwise could be decreased. Sediment samples with $10<\mathrm{MPI}, 5<\mathrm{MPI}<10,3<\mathrm{MPI}<5,2<\mathrm{MPI}<3,1<\mathrm{MPI}<2$ and $\mathrm{MPI}<1$ were categorized as extremely polluted, heavily, moderately-heavily, moderately, slightly and unpolluted, respectively (Brady et al. 2015). According to Fig. S2, indicating the spatial distribution pattern of MPI, the Edremit Gulf, is entirely polluted starting from slightly to heavily. In the southwestern corner of the area, northern side of the Alibey island heavily polluted sediments were observed close to old $\mathrm{Pb}$ mining area (MPI: 6.6). Similarly to the spatial distribution of the As and Pb EFs (Fig. 4c,d), the MPI is decreasing to moderately and slightly polluted ranges towards the east and north respectively. The degradation of sediment quality is coherent with the hydrological regime forcing the dispersion of treated wastewater of the outfall systems both southern and northern side of the Gulf.

\section{Sediment quality parameters}

The limit values determined in the sediment quality guidelines (SQG) and the results of the metal analysis performed in the samples were given in Table 1. As seen in Fig. 6 showing the entire data, our study showed that all measured Zn concentrations in sediment samples were below the corresponding TEL value indicating rare (9\%) toxic effect that is not associated with adverse biological effects. Mean levels of $\mathrm{As}, \mathrm{Cr}, \mathrm{Cu}$ and $\mathrm{Pb}$ were between corresponding TELs and PELs which only the mean value of $\mathrm{Ni}$ exceeds $\mathrm{PEL}$. As, $\mathrm{Pb}, \mathrm{Cr}$, Cu and $\mathrm{Ni}$ concentrations were in the range between the corresponding TELs and PELs by $90 \%, 78 \%, 75 \%, 65 \%$ and $35 \%$ respectively, which indicate occasionally toxic (22\%) adverse biological effects. $\mathrm{Ni}, \mathrm{As}$ and $\mathrm{Cr}$ were the limited metals with concentrations exceeding the PELs by $60 \%, 10 \%$ and $6 \%$ respectively and this indicates Ni has the highest adverse biological effect as frequently toxic (56\%). Therefore, adverse biological effects may be formed more 
frequently due to the concentrations of $\mathrm{Ni}$, As and $\mathrm{Cr}$. According to the NOAA sediment quality criteria (ERL and ERM), the levels of $\mathrm{Zn}$ for all sediments were less than the corresponding ERL which indicates minimal toxic (25\%) effect. The concentrations for $\mathrm{Pb}, \mathrm{Cu}, \mathrm{Cr}$ and $\mathrm{Ni}$ are lower than the corresponding ERLs by $94 \%, 90 \%, 50 \%$ and $12 \%$, respectively. As, $\mathrm{Cr}, \mathrm{Ni}, \mathrm{Cu}$ and $\mathrm{Pb}$ contents are in the range of the corresponding ERLs and ERMs by $100 \%, 50 \%, 41 \%, 10 \%$ and $6 \%$ respectively indicating occasional adverse effects. Ni was the only metal with levels exceeding the ERM (by $47 \%$ ) which indicates frequently toxic (75100\%) effects (Fig. 6).

\section{Toxicity estimation and risk assessment}

To classify the sediments toxicities several principles have been defined. Mearns et al. (1986), categorized the data of amphipod survival tests nontoxic (average survival:96-96.5\%), marginally toxic (average survival:76.5-83\%), clearly toxic (average survival $<76 \%$ ), and highly toxic (average survival $<20 \%$ ). Later Swartz et al. (1995) categorized the results of amphipod survival tests as nontoxic (<13\% mortality), uncertain (13-24\% mortality), or toxic ( $>24 \%$ mortality) and according to Hansen et al. (1996); sediments were categorized as toxic if mortality was higher than $24 \%$, while sediments with $\leq 24 \%$ mortality were thought as nontoxic. Like Zhang et al. (2017) this research regarding the uncertainties in the toxicity estimation results of different organisms and end points, a wider toxicity ranges of $10-30 \%$ was characterized as "uncertain", $<10 \%$ was defined as "nontoxic", while > $30 \%$ was "toxic".

If more than $75 \%$ of sediment samples in the marine environment are correctly estimated to be toxic or nontoxic, sediment quality guidelines (SQGs) are considered to supply a reliable basis for evaluating sediment quality (Long et al. 1998; MacDonald et al. 2000). Based on this, the concentrations of 6 trace elements ( $\mathrm{As}, \mathrm{Cr}, \mathrm{Cu}, \mathrm{Ni}, \mathrm{Pb}$ and $\mathrm{Zn}$ ) determined in the surface sediment samples of the Edremit Gulf were compared with the TEL and PEL values in the previous sections (Table 1, Fig. 6). When sediment quality guidelines (SQGs) are evaluated by considering the number of samples with $Q_{P E L}>1, Q_{P E L} \leq 1$ $\leq Q_{T E L}$ and $Q_{T E L}<1$ calculated on the basis of the given TEL and PEL, all $Q_{T E L}$ and $Q_{P E L}$ values vary between 4.9-24.4 and 1.26.7 respectively (Fig. S3, top). Based on these data, virtually all of the sampling locations are higher than 1 both for $\mathrm{Q}_{\mathrm{TEL}}$ and $\mathrm{Q}_{\mathrm{PEL}}$ and the whole area shows toxic (30\%) characteristics as indicated in Fig. S3.

Figure S3 demonstrates the contribution of each trace element to the total toxicological risks, i.e the ratio of $Q_{i, P E L} / Q_{P E L} \cdot \operatorname{In}$ the 68 sediment samples, the $\mathrm{Q}_{\mathrm{i}, \mathrm{PEL}}$ of $\mathrm{As}, \mathrm{Cr}, \mathrm{Cu}, \mathrm{Ni}, \mathrm{Pb}$ and $\mathrm{Zn}$ accounted for $8.45 \%-41.84 \%, 9.73 \%-25.57 \%, 2.76 \%-11.38 \%$, $14.82 \%-52.86 \%, 4.48 \%-21.04$ and $4.22 \%-15.17 \%$ of $Q_{P E L}$, respectively. The results proposed that Ni made a dominant contribution to the toxicities of trace element mixtures in the sediments, which was followed by $\mathrm{As}, \mathrm{Cr}, \mathrm{Pb}, \mathrm{Zn}$ and $\mathrm{Cu}$. These results showed that $\mathrm{Ni}$ and $\mathrm{As}$ were the major metal contaminants in the sediments of Edremit Gulf. In contrast, the risks caused by $\mathrm{Cu}$ and $\mathrm{Zn}$ were relatively low.

MacDonald (1994), proposed SQGs where the adverse effects of TEL is considered reliable if the minimal effect range is less than $10 \%$, while if the adverse effects exceed $65 \%$ of the probable effect range the PEL is considered consistent. Thus, the TEL of trace metals in sediments would display only limited acute toxic impacts to exposed aquatic organisms. However, if the exposure period is long enough the possibility of chronic toxic impacts cannot be refused. Hence, a TRI integrating the TEL and PEL was used to evaluate toxic risks in terms of both chronic and acute toxic impacts in aquatic organisms exposed to sediment polluted by trace elements. Overall TRI results, displayed moderate toxic risk $(10<\mathrm{TRI} \leq 15)$ at 23 locations, while no toxic risk $(\mathrm{TRI} \leq 5)$ and considerable toxic risk $(15<\mathrm{TRI} \leq 20)$ were observed at three $(\mathrm{Stn} ; 9,18,55)$ and two $(\mathrm{Stn} ; 24,45)$ stations respectively (Fig. 7). The mean $\mathrm{TRI}_{\mathrm{i}}$ values of metals showed a decreasing order of $\mathrm{TRI}_{\mathrm{As}}(2.91)>\mathrm{TRI}_{\mathrm{Ni}}(2.62)>\mathrm{TRI}_{\mathrm{Cr}}$ $(1.23)>\mathrm{TRI}_{\mathrm{Pb}}(0.87)>\mathrm{TRI}_{\mathrm{Cu}}(0.86)>\mathrm{TRI}_{\mathrm{Zn}}(0.45)$ with mean contributions of $33.5 \%, 27.8 \%, 13.3 \%, 10.5 \%, 9.8 \%, 5.2 \%$ respectively. Calculated TRI results indicate that As accounts for most of the overall sediment toxicity. Compared to the others, the most prominent difference of $\mathrm{As}$ and $\mathrm{Ni}$, which provide the most important contribution to $\mathrm{TRI}$, is mainly their relatively low TEL values and their high concentrations measured in surface sediments. This points out the potential toxicity of sediments in Edremit Gulf and stands out As and Ni as two heavy metals deserving more concern.

Sediment Transport Patterns

Page 10/25 
Using the GSTA model the sediment transport vectors were generated. The transport pattern that was developed is identified and displayed in Fig. 8, which shows the grain size trend and transport directions, denoted by arrows, in the Edremit Gulf. The vectors represented the net transport directions of surface sediments, and the vector length indicates the importance of grain size trend, rather than the scale of transport rate.

The circulation of the coastal marine reflects the directional flow features on the dispersion and regional tendency of the sediments. The primary driving forces for sediment transport in shallow nearshore are wind induced waves and associated movements. The conclusion of the ADCP measurements in Edremit Gulf showed that currents were primarily driven by winds and the associated fluctuation of sea surface layers. The ADCP data recorded for the shallow $(<50 \mathrm{~m})$ zone demonstrated that the surface currents are generally slightly faster than the bottom currents that form in the opposite direction (TUBITAK 115Y180, 2018). The surface waters that moved towards the east at the southern zone and in the opposite direction on the northern coastal areas displayed complex and small-scale cycles that occur in the southern part of the Gulf because of the coastal structure. Small scale cyclonic cycles in the comparatively shallow eastern part and an anti-cyclonic cycle in the coastal zone around the eastern section of the islands were observed. The general circulation of this region is not only winddriven but also the general thermohaline circulation of the Aegean Sea, particularly during the summer months, contribute significantly to the deep-water circulation system of Edremit Gulf.

In this study, two distinct sediment transport modes consisting of strong basinward transport sediments consisting of mainly river-born and westerly directed weak transport of basin sediments were recognized in Edremit Gulf. As tracers for sediment movement elemental, carbonate, carbon content and contamination assessment data were evaluated. Within this system, utilizing tracing and hydrodynamic information of the pattern of sediment transport was also evaluated. Even though the main controls of sediment transport are definitely hydrodynamic, the depositional zones are strongly influenced by the topography where the geomorphological characteristics trapping the sediments. Spatial distribution of the trace elements, PCA components, degree of sediment pollution and several other indices are consistent with the determined residual grain-size trend pattern of Edremit Gulf transport vectors (Fig. 8).

\section{Conclusion}

In this present study, we investigated geochemical distribution, controlling factors, possible sources and pollution indexes of six toxic elements (i.e. As, $\mathrm{Cr}, \mathrm{Cu}, \mathrm{Ni}, \mathrm{Pb}$ and $\mathrm{Zn}$ ) in the underexplored Edremit Gulf, Eastern Aegean Sea.

- The mean concentrations of six toxic elements showed the descending order of $\mathrm{Cr}>\mathrm{Zn}>\mathrm{Ni}>\mathrm{Pb}>\mathrm{As}>\mathrm{Cu}$ and only $\mathrm{As}$ was higher than their corresponding background values.

- The sediment particle size distribution showed a transition from the coastal areas of western entries of the Gulf mostly containing coarser sediments towards the central zone from deeper western basin to shallower eastern coastal areas of the Gulf where sediment is finer.

- The results illustrated that heavy metals exhibit two spatial distribution patterns ( $\mathrm{As}, \mathrm{Cr}, \mathrm{Ni}$ and $\mathrm{Cu}, \mathrm{Pb}, \mathrm{Zn}$ ). All these elements were also positively and significantly correlated with the fine fraction of the sediment.

- The multivariate statistical methods with element concentrations and correlation analysis indicated that the study area is predominantly under the pressure of anthropogenic source. The enrichments of $\mathrm{As}$ and $\mathrm{Pb}$ are remarkable in the sediment, with the consistently high $\mathrm{EF}, \mathrm{I}_{\text {geo }}$ and $\mathrm{CF}$ values.

- In accordance with the TEL-PEL and ERL-ERM values, except for the presence of a relatively high proportion of Ni and partly As, which possibly cause adverse biological effects, the other elements would have few adverse biological effects. Toxicological risk estimations $\mathrm{Q}_{\mathrm{TEL}}$ and $\mathrm{Q}_{\mathrm{PEL}}$ indicated that $\mathrm{Ni}$ and $\mathrm{As}$ were the major trace element contaminants in the sediments of Edremit Gulf. Furthermore, the influencing mechanisms of the changing sediment conditions on the movement and transformation of trace elements in the coastal areas of the Edremit Gulf need to be investigated in the future. 
Using the Gao-Collins grain size trend model, it was detected that the transportation of fine sediment was related to the residual currents, which was consistent with the trace element distribution and calculated pollution patterns. This contribution portrays on pollution problems and can provide in-depth understandings of the contaminant transport processes, thus supporting the practices of pollution control and prevention in the Edremit Gulf.

\section{Declarations}

\section{Ethical approval}

Not applicable.

\section{Consent to Participate}

Not applicable.

\section{Consent to Publish}

Not applicable.

\section{Availability of data and materials}

The data sets used and/or analyzed during the current study are available from the corresponding author on reasonable request.

\section{Competing interests}

The authors declare that they have no competing interests.

\section{Funding}

Project funded by the Scientific and Technological Research Council of Turkey (TUBITAK) Project Number: $115 Y 180$.

\section{Authors' contributions}

Muhammet Duman conceived and designed the study. Muhammet Duman, Atilla Hüsnü Eronat and Ezgi Talas completed marine survey and collect sediment samples. Ezgi Talas, Filiz Kucuksezgin and Tarık İlhan conducted the lab experiment. Muhammet Duman, Filiz Kucuksezgin, Atilla Hüsnü Eronat and Şenol Aydın drafted the initial manuscript.

\section{Acknowledgements}

All survey data used in this study were taken within the scope of TUBITAK 115Y180 "Classification and Mapping of Seabed Features of Aegean Sea Coastal Areas", and we would like to thank all the participants who contributed to the project.

\section{References}

1. Abbas A, Al-Amer AM, Laoui T, Al-Marri MJ, Nasser MS, Khraisheh M, Atieh MA (2016) Heavy metal removal from aqueous solution by advanced carbon nanotubes: Critical review of adsorption applications. Sep Purif Technol 157:141-161

2. Abbasia A, Mirekhtiary F (2020) Heavy metals and natural radioactivity concentration in sediments of the Mediterranean Sea coast. Mar Pollut Bull 154:111041

3. Aguilar Pesantes A, Peña Carpio E, Vitvar T, María Mahamud López M, Menéndez-Aguado JM (2019) A multi-index analysis approach to heavy metal pollution assessment in river sediments in the Ponce Enríquez area. Ecuador Water, 11(3), 590 
4. Akiska S, Demirela G, Sayili S (2013) Geology, mineralogy and the Pb, S isotope study of the Kalkım Pb-Zn \pm Cu deposits, Biga Peninsula, NW-Turkey. J Geosci 58(4):379-396

5. Balkıs N, Aksu A, Altuğ G (2020) Toxic Metal Pollution in the Surface Sediments from Güllük Bay (Muğla-Turkey). Geological Bulletin of Turkey 63:117-124

6. Baran A, Wieczorek J, Mazurek R, Urban'ski K, Klimkowicz-Pawlas A (2018) Potential ecological risk assessment and predicting zinc accumulation in soils. Environ Geochem Health 40(1):435-450

7. Ben Amor R, Yahyaoui A, Abidi M, Chouba L, Gueddari M (2019) Bioavailability and assessment of metal contamination in surface sediments of rades-hamam lif coast, around meliane river (Gulf of Tunis, Tunisia, Mediterranean Sea). J. Chem. 4284987, https://doi.org/10.1155/2019/4284987

8. Birch GF (2017) Determination of sediment metal background concentrations and enrichment in marine environments - a critical review. Sci Total Environ 580:813-831

9. Bourliva A, Kantiranis N, Papadopoulou L, Aidona E, Christophoridis C, Kollias P, Evgenakis M, Fytianos K (2018) Seasonal and spatial variations of magnetic susceptibility and potentially toxic elements (PTEs) in road dusts of Thessaloniki city, Greece: a one-year monitoring period. Sci Total Environ 639:417-427

10. Brady JP, Ayoko GA, Martens WN, Goonetilleke A (2015) Development of a hybrid pollution index for heavy metals in marine and estuarine sediments. Environ Monit Assess 187(5):306

11. Cai MH, Lin J, Hong QQ, Wang Y, Cai MG (2011) Content and distribution of trace metals in surface sediments from the northern Bering Sea, Chukchi Sea and adjacent Arctic areas. Mar Pollut Bull 63:523-527

12. Caeiro S, Costa MH, Ramos TB, Fernandes F, Silveria N, Coimbra A, Medeiros G, Painho M (2005) Assessing heavy metal contamination in Sado Estuary sediment: An index analysis approach. Ecol Ind 5:151-169

13. Chang YH, Scrimshaw MD, Lester JN (2001) A revised grain-size trend analysis program to define net sediment transport pathways. Computer Geosciences 27:109-114

14. Chakravarty IM, Patgiri AD (2009) Metal pollution assessment in sediments of the Dikrong River, N.E. India. Journal of Human Ecology 27(1):63-67

15. Chen H, Teng Y, Lu S, Wang Y, Wang J (2015) Contamination features and health risk of soil heavy metals in China. Science of The Total Environment, 512(C), 143-153

16. Christophoridis C, Bourlive A, Evgenakis E, Papadopoulou L, Fytianos K (2019) Effets on anthropogenic activities on the levels of heavy metals in marine surface sediments of the Thessaloniki Bay, Northern Greece: Spatial distribution, sourcers and contamination assesment. Microchem J 149:104001

17. Çolakoğlu AR (2000) The characteristics of Kucukdere epithermal (Havran-Balikesir) gold vein. Geological Bulletin of Turkey 43:99-110

18. David E, Cosio C (2021) New Insights into Impacts of Toxic Metals in Aquatic Environments. Environments 2021, 8, 1

19. Duc DM, Thanh DX, Quynh DT, McLaren P (2016) Analysis of sediment distribution and transport for mitigation of sand deposition hazard in Tam Quan estuary, Vietnam. Environ Earth Sci 75:741

20. Duman M, Duman Ş, Lyons TW, Avci M, İzdar E, Demirkurt E (2006) Geochemistry and sedimentology of shelf and upper slope sediments of the south-central Black Sea. Mar Geol 227(1-2):51-65

21. Duman M, Avci M, Duman Ş, Demirkurt E, Düzbastilar MK (2004) Surficial sediment distribution and net sediment transport pattern in Izmir Bay, western Turkey. Cont Shelf Res 24(9):965-981

22. Elias P, Gbadegesin A (2011) Spatial relationships of urban land use, soils and heavy metal concentrations in Lagos Mainland Area. Journal of Applied Sciences Environmental Management 15:391-399

23. Feng H, Han X, Zhang W, Yu L (2004) A preliminary study of heavy metal contamination in Yangtze River intertidal zone due to urbanization. Marine Pollution Bulletin, 49(11-12), 910-915

24. Förstner U, Wittmann GTW (1983) Metal Pollution in the Aquatic Environment. Springer, Heidelberg, 488p

25. Folk RL (1974) Petrology of Sedimentary Rocks. Hemphil, Austin

Page $13 / 25$ 
26. Gao S (1996) A Fortran program for grain-size trend analysis to define net sediment transport pathways. Comput Geosci 22(4):449-452

27. Gao X, Chen CTA (2012) Heavy metal pollution status in surface sediments of thecoastal Bohai Bay. Water Res 46:19011911

28. Gao S, Collins M (1992) Net sediment transport patterns inferred from grain-size trends, based upon definition of "transport vectors". Sed Geol 80(1-2):47-60

29. Gao S, Collins MB, Lanckneus J, Moor GD, Lancker VV (1994) Grain size trends asso-ciated with net sediment transport patterns: an example from the Belgian continen-tal shelf. Mar Geol 121:171-185

30. Giamali. C, Kontakiotis G, Koskeridou E, loakim. C, Antonarakou A (2020) Key Environmental Factors Controlling Planktonic Foraminiferal and Pteropod Community's Response to Late Quaternary Hydroclimate Changes in the South Aegean Sea (Eastern Mediterranean). Journal of Marine Science Engineering 8(9):709

31. Giordano R, Lombardi G, Ciaralli L, Beccaloni E, Sepe A, Ciprotti M, Costantini S (1999) Major and trace elements in sediments from Terra Nova Bay, Antarctica. Sci Total Environ 227:29-40

32. Hakanson $L$ (1980) An ecological risk index for aquatic pollution control.a sedimentological approach. Water Res 14(8):975-1001

33. Hansen DJ, Berry WJ, Boothman WS, Pesch CE, Mahony JD, Di Toro DM, Robson DL, Ankley GT, Ma D, Yan Q (1996) Predicting the toxicity of metal-contaminated field sediments using interstitial concentration of metals and acid-volatile sulfide normalizations. Environ Toxicol Chem 15:2080-2094

34. Héquette A, Hemdane Y, Anthony EJ (2008) Determination of sediment transport paths in macrotidal shoreface environments: a comparison of grain-size trend analysis with near-bed current measurements. J Coastal Res 24:695-707

35. Hyun S, Lee CH, Lee T, Choi JW (2007) Anthropogenic contributions to heavy metal distributions in the surface sediments of Masan Bay. Korea Marine Pollution Bulletin 54(7):1059-1068

36. Ianni C, Magi E, Soggia F, Rivaro P, Frache R (2010) Trace metal speciation in coastal and off-shore sediments from Ross Sea (Antarctica). Microchem J 96:203-212

37. Jeong H, Choi JY, Choi DH, Noh JH, Ra K (2021) Heavy metal pollution assessment in coastal sediments and bioaccumulation on seagrass (Enhalus acoroides) of Palau. Mar Pollut Bull 163:111912

38. Karageorgis AP, Botsou F, Kaberi H, Iliakis S (2020) Geochemistry of major and trace elements in surface sediments of the Saronikos Gulf (Greece): Assessment of contamination between 1999 and 2018. Sci Total Environ 717:137406

39. Karditsa A, Poulos SE, Botsou F, Alexakis D, Stamatakis M (2014) Investigation of major and trace elements distribution pattern and pollution status of the surficial sediments of a microtidal inner shelf influenced by a transboundary river. The case of the Alexandroupolis Gulf (northeastern Aegean Sea, Greece). J Geochem Explor 146:105-118

40. Khan R, Saxena A, Shukla S (2021) Assessment of the impact of COVID-19 lockdown on the heavy metal pollution in the River Gomti, Lucknow city, Uttar Pradesh, India. Environ Qual. Manage., 1-9

41. Khan MZH, Hasan MR, Khan M, Aktar S, Fatema K (2017) Distribution of heavy metals in surface sediments of the bay of Bengal coast. J Toxicol 1-7:9235764

42. Koukounari I, Paraskevopoulou V, Karditsa A, Koulouri P, Poulos S, Dounas C, Dassenakis M (2020) Trace metal concentrations in the offshore surficial sediment of the Heraklio Gulf (Crete Island, East Mediterranean Sea). Mediterranean Marine Science 21(1):84-104

43. Liu W, Zhao J, Ouyang Z, Söderlund L, Liu G (2005) Impacts of sewage irrigation on heavy metal distribution and contamination in Beijing, China. Environ Int 31(6):805-812

44. Long ER, Field LJ, MacDonald DD (1998) Predicting toxicity in marine sediments with numerical sediment quality guidelines. Environ Toxicol Chem 17:714-727

45. Long ER, McDonald DD, Smith SL, Calder FD (1995) Incidence of Adverse Biological Effects Within Range of Chemical Concentrations in Marine and Estuarine Sediments. Environ Manage 19(1):81-97 
46. Loring D:H, Rantala RTT (1992) Manual for the geochemical analyses of marine sediments and suspended particulate matter. Earth Sci Rev 32(4):235-283

47. Lu X, Wang L, Li LY, Lei K, Huang L, Kang D (2010) Multivariate statistical analysis of heavy metals in street dust of Baoji, NW China. J Hazard Mater 173:744-749

48. MacDonald DD, Ingersoll CG, Berger TA (2000) Development and Evaluation of Consensus-Based Sediment Quality Guidelines for Freshwater Ecosystems. Arch Environ Contam Toxicol 39:20-31

49. MacDonald DD (1994) Approach to the Assessment of Sediment Quality in Florida Coastal Waters. Volume 1-Development and Evaluation of the Sediment Quality Assessment Guidelines. Report prepared for Florida Department of Environmental Protection, Tallahassee

50. Martínez-Guijarro R, Paches M, Romero I, Aguado D (2019) Enrichment and contamination level of trace metals in the Mediterranean marine sediments of Spain. Science of The Total Environment 693:133566

51. Mazurek R, Kowalska J, Gąsiorek M, Zadrożny P, Józefowska A, Zaleski T (2017) Assessment of heavy metals contamination in surface layers of Roztocze National Park forest soils (SE Poland) by indices of pollution. Chemosphere 168:839-850

52. McLaren P, Tear G (2014) A sediment trend analysis (STA) in support of dredged material management in Lyttelton Harbour, Christchurch, New Zealand. J Coastal Res 30(3):438-447

53. Mearns AJ, Swartz RC, Cummins JM, Dinnel PA, Plesha P, Chapman PM (1986) Inter-laboratory comparison of a sediment toxicity test using the marine amphipod, Rhepoxynius abronius. Marine Environmental Research 19:13-37

54. Meric E, Avşar N, Nazik A, Kocak F, Yücesoy-Eryılmaz F, Eryılmaz M, Barut IF, Yokeş MB, Dincer F, Esenli F, Esenli V, Özdemir Z, Türker A, Aydın. Ş (2012) New findings on the effects of oceanographic characteristics on the benthic foraminifer, ostracod and bryozoan assemblages in Gulf of Edremit (Balıkesir) coastal zones. TAPG Bulletin, 24(2), 31-77

55. Müller G (1967) Methods in sedimentary petrology. The Hafner Publishing Company, Germany, $216 \mathrm{p}$

56. Niencheski LFH, Windom HL, Moore WS (2014) Controls on water column chemistry of the southern Brazilian continental shelf. Cont Shelf Res 88:126-139

57. Oyman T (2010) Geochemistry, mineralogy and genesis of the Ayazmant Fe-Cu skarn deposit in Ayvalik, (Balikesir), Turkey. Ore Geol Rev 37:175-201

58. Pan K, Wang WX (2012) Trace metal contamination in estuarine and coastal envi-ronments in China. Science of The Total Environment 421-422:3-16

59. Papatheodorou G, Avramidis P, Fakiris E, Christodoulou D, Kontopoulos N (2012) Bed diversity in the shallow water environment of Pappas lagoon in Greece. Int J Sedim Res 27(1):1-17

60. Passos EA, Alves JC, Santos IS, Alves JPH, Garcia CAB, Costa A (2010) Assessment of trace metals contamination in estuarine sediments using a sequential extraction technique and principal component analysis. Microchem J 96(1):50-57

61. Pejman A, Gholamrez Nabi B, Saeedi M, Baghvanda A (2015) A new index for assessing heavy metals contamination in sediments. A case study Ecological Indicators 58:365-373

62. Poizot E, Mear Y (2010) Using a GIS to enhance grain size trend analysis. Environ Model Softw 25:513-525

63. Poizot E, Méar Y, Biscara L (2008) Sediment trend analysis through the variation of granulometric parameters: a review of theories and applications. Earth-Sci Rev 86:15-41

64. Radomirović M, Tanaskovski B, Pezo L, Ceccotto F, Cantaluppi C, Onjia A, Stanković S (2021) Spatial and temporal distribution of pollution indices in marine surface sediments-a chemometric approach. Environ Sci Pollut Res. https://doi.org/10.1007/s11356-021-13644-9

65. Qi S, Leipe T, Rueckert P, Di Z, Harff J (2010) Geochemical sourecs, deposition and enrichment of heavy metals in short sediment cores from the Pearl River Estuary, Southern China. J Mar Syst 82:S28-S42

66. Saleem M, Iqbal J, Shah MH (2015) Geochemical speciation, anthropogenic contamination, risk assessment and source identification of selected metals in freshwater sediments- A case study from Mangla Lake, Pakistan. Environmental Nanotechnology Monitoring Management 4:27-36

Page $15 / 25$ 
67. Shen F, Mao L, Sun R, Du J, Tan Z, Ding M (2019) Contamination Evaluation and Source Identification of Heavy Metals in the Sediments from the Lishui River Watershed, Southern China. International Journal of Environmental Research Public Health 16(3):336

68. Somay AM (2016) Importance of hydrogeochemical processes in the coastal wetlands: A case study from Edremit-Dalyan coastal wetland, Balıkesir-Turkey. J Afr Earth Sc 123:29-38

69. Stamatis N, Kamidis N, Pigada P, Sylaios G, Koutrakis E (2019) Quality Indicators and Possible Ecological Risks of Heavy Metals in the Sediments of three Semi-closed East Mediterranean Gulfs. Toxics 7:30

70. Sutherland RA (2000) Bed sediment-associated trace metals in an urban stream. Oahu Hawaii Environmental Geology 39(6):611-627

71. Swartz RC, Schults DW, Ozretich RJ, Lamberson JO, Cole FA, Ferraro SP et al (1995) $\Sigma P A H:$ a model to predict the toxicity of polynuclear aromatic hydrocarbon mixtures in field-collected sediments. Environ Toxicol Chem 11:1977-1987

72. Tang IY, Yan DYS, Lo IMC, Liu T (2015) Pulverized fuel ash solidification/stabilization of waste: comparison between beneficial reuse of contaminated marine mud and sediment. Journal of Environmental Engineering Landscape 23(3):202210

73. Tessier A, Campbell PGC, Auclair JC, Bisson M (1984) Relationships between the partitioning of trace metals in sediments their accumulation in the tissues of the freshwater mollusc Elliptio Complanata in a mining area. Can J Fish Aquat Sci 41(10):1463-1472

74. Tornero V, Arias AM, Julian Blasco J (2014) Trace element contamination in the Guadalquivir River Estuary ten years after the Aznalcóllar mine spill. Mar Pollut Bull 86(1-2):349-360

75. Tribovillard N (2020) Arsenic in marine sediments: how robust a redox proxy?. Geology, Paleogeography, Paleoclimatology, Paleoecology, 550, 109745

76. TUBITAK 115Y180 (2018) Ege kıyı sularında deniz taban yapılarının sınıflandırılması ve haritalanması. Duman M, Küçüksezgin F, Akçalı B, Kaboğlu G, Beşiktepe Ş, Final Report, 95p

77. Turekian KK, Wedepohl KH (1961) Distribution of the elements in some major units of the earth's crust. Geol Soc Am Bull 72:175-192

78. Wang X, Fu R, Li H, Zhang Y, Lu M, Xiao K, Zhang X, Zheng C, Xiong Y (2020) Heavy metal contamination in surface sediments: A comprehensive, large-scale evaluation for the Bohai Sea, China. Environ Pollut 260:113986

79. Wasserman JC, Oliveira FBL, Bidarra M (1998) Cu and Fe associated with humic acids in sediments of a tropical coastal lagoon. Org Geochem 28:813-822

80. Weiping S, Jianjun Y, Xiaoqun X, Weiyan Z, Ruijuan L, Jianming P (2014) Distribution and sources of heavy metals in the sediment of Xiangshan Bay. Acta Oceanol Sin 33(4):101-107

81. Weis JS (2014) Physiological, Developmental and Behavioral Effects of Marine Pollution. Springer, New York, ISBN: 97894-007-6948-9

82. Wu B, Wang G, Wu J, Fu Q, Liu C (2014) Sources of Heavy Metals in Surface Sediments and an Ecological Risk Assessment from Two Adjacent Plateau Reservoirs. PLoS ONE 9(7):e102101

83. Xu G, Pei S, Liu J, Gao M, Hu G, Kong X (2015) Surface sediment properties and heavy metal pollution assessment in the near-shore area, north Shandong Peninsula. Mar Pollut Bull 95(1):395-401

84. Yılmaz H (2007) Stream sediment geochemical exploration for gold in the kazdağ Dome in the Biga peninsula, western Turkey. Turkish Journal of Earth Sciences 16:33-55

85. Yiğit O (2012) A prospective sector in the Tethyan metallogenic belt: geology and geochronology of mineral deposits in the Biga Peninsula, NW Turkey. Ore Geology Reviews 46:118-148

86. Yiğit O (2009) Mineral deposits of Turkey in relation to Tethyan Metallogeny: implications for future mineral exploration. Econ Geol 104(1):19-51

87. Yiğit O (2006) Gold in Turkey-a missing link in Tethyan metallogeny. Ore Geology Reviews 28:147-179 
88. Yümün Z, Önce M (2017) Monitoring heavy metal pollution in foraminifera from the Gulf of Edremit (northeastern Aegean Sea) between İzmir, Balıkesir and Çanakkale (Turkey). J Afr Earth Sc 130:110-124

89. Zhang Y, Yuwei H, Yang J, Zhu L, Zhong W (2017) Toxicities and risk assessment of heavy metals in sediments of Taihu Lake, China, based on sediment quality guidelines. J Environ Sci 62:31-38

90. Zhang G, Bai J, Zhao Q, Lu Q, Jia J, Wen X (2016) Heavy metals in wetland soils along a wetland-forming chronosequence in the Yellow River Delta of China: levels, sources and toxic risks. Ecol Ind 69:252-260

91. Zhang C, Yu ZG, Zeng GM, Jiang M, Yang ZZ, Cui F, Zhu MY, Shen LQ, Hu L (2014) Effects of sediment geochemical properties on heavy metal bioavailability. Environ Int 73:270-281

92. Zhong L, Liming L, Jiewen Y (2010) Assessment of heavy metals contamination of paddy soil in Xiangyin county, China. In Symposium 4.1.2 management and protection of receiving environments, 19th World Congress of Soil Science, Soil Solutions for a Changing World

\section{Tables}

Table 1

Summary statistics (minimum, maximum, mean, standard deviation) of sediment grain-size and measured parameters, avg shale, local background values and threshold-midrange effect of sediment quality guidelines for metals.

\begin{tabular}{|c|c|c|c|c|c|c|c|c|c|c|c|c|c|}
\hline & As & $\mathrm{Cr}$ & $\mathrm{Cu}$ & $\mathrm{Ni}$ & $\mathrm{Pb}$ & $\mathrm{Zn}$ & Al & $\mathrm{Fe}$ & Sand & Silt & Clay & $\mathrm{C}_{\text {org }}$ & Carb. \\
\hline & \multicolumn{6}{|c|}{$(\mathrm{mg} / \mathrm{kg})$} & \multicolumn{7}{|l|}{ (\%) } \\
\hline Min. & 12 & 26 & 6.4 & 14.6 & 16.8 & 31 & 1.8 & 1.24 & 0.99 & 2 & 0 & 0.37 & 7.24 \\
\hline Max. & 63 & 200 & 51.5 & 136.9 & 63.7 & 123 & 8.17 & 4.86 & 96.9 & 98.72 & 40.16 & 3.44 & 65.19 \\
\hline Mean & 29.2 & 86.2 & 22.7 & 55.2 & 35.9 & 72.3 & 6.15 & 3.21 & 45.2 & 42.7 & 9.95 & 1.67 & 26.9 \\
\hline SD & 9.73 & 39.79 & 9.2 & 28.19 & 8.24 & 19.72 & 1.43 & 0.77 & 30.48 & 26.02 & 8.91 & 0.59 & 13.87 \\
\hline $\begin{array}{l}\text { Background } \\
57\end{array}$ & 18 & 105 & 27.5 & 88.7 & 36.4 & 85 & 7.36 & 3.90 & & & & & \\
\hline $\begin{array}{l}\text { Background } \\
58\end{array}$ & 23 & 103 & 32.7 & 83.6 & 37.3 & 84 & 7.42 & 4.06 & & & & & \\
\hline $\begin{array}{l}\text { Background } \\
60\end{array}$ & 33 & 117 & 48.9 & 77.8 & 45.2 & 107 & 7.64 & 4.97 & & & & & \\
\hline Avg. Shale & 13 & 90 & 45 & 68 & 20 & 95 & 8.1 & 4.72 & & & & & \\
\hline $\mathrm{TEL}^{\text {**}}$ & 7.2 & 52.3 & 18.7 & 15.9 & 30.2 & 124 & & & & & & & \\
\hline$P E L^{* \star}$ & 41.6 & 160.4 & 108.2 & 42.8 & 112 & 271 & & & & & & & \\
\hline$E R L^{* \star *}$ & 8.2 & 81 & 34 & 20.9 & 46.7 & 150 & & & & & & & \\
\hline ERM $^{\star \star \star}$ & 70 & 370 & 270 & 51.6 & 218 & 410 & & & & & & & \\
\hline
\end{tabular}

${ }^{*}$ Turekian and Wedepohl (1961)

${ }^{\star \star}$ MacDonald et al. (2000), Xu et al. (2016)

${ }^{\star * \star}$ Long et al. $(1995,1998)$

Table 2 
Ranges and mean or median values (in parentheses) of trace metal concentrations $(\mathrm{mg} / \mathrm{kg})$ in Edremit Gulf and the Mediterranean Sea (na: not available).

\begin{tabular}{|c|c|c|c|c|c|c|}
\hline Area (reference) & As & $\mathrm{Cr}$ & $\mathrm{Cu}$ & $\mathrm{Ni}$ & $\mathrm{Pb}$ & $\mathrm{Zn}$ \\
\hline Edremit Gulf (This study) & $\begin{array}{l}12-63 \\
(29.2)\end{array}$ & $\begin{array}{l}26-200 \\
(86.2)\end{array}$ & $\begin{array}{l}6.4-51.5 \\
(22.7)\end{array}$ & $\begin{array}{l}14.6-136.9 \\
(55.2)\end{array}$ & $\begin{array}{l}16.8-63.7 \\
(35.9)\end{array}$ & $\begin{array}{l}31-123 \\
(72.3)\end{array}$ \\
\hline $\begin{array}{l}\text { Heraklion Gulf } \\
\text { (Koukounari et al., 2020) }\end{array}$ & na & $\begin{array}{l}83.8-152 \\
(114)\end{array}$ & $\begin{array}{l}8.9-27.6 \\
(18.9)\end{array}$ & na & $\begin{array}{l}6.5-23.0 \\
(11.3)\end{array}$ & $\begin{array}{l}24.6-68.5 \\
(45.0)\end{array}$ \\
\hline $\begin{array}{l}\text { Alexandroupolis Gulf, NE } \\
\text { Aegean (Karditsa et } \\
\text { al.,2014) }\end{array}$ & na & $\begin{array}{l}23-221 \\
(66)\end{array}$ & $\begin{array}{l}3-78 \\
(20)\end{array}$ & na & $\begin{array}{l}9-113 \\
(38)\end{array}$ & $\begin{array}{l}37-248 \\
(93)\end{array}$ \\
\hline $\begin{array}{l}\text { Valencian Community, Spain } \\
\text { (Martinez-Guijarro, 2019) }\end{array}$ & $\begin{array}{l}1.8-47.1 \\
(15.7)\end{array}$ & $\begin{array}{l}2.4-37.5 \\
(15.6)\end{array}$ & $\begin{array}{l}1.1-7.9 \\
(3.2)\end{array}$ & $\begin{array}{l}1.3-18.3 \\
(8.0)\end{array}$ & $\begin{array}{l}1.7-12.6 \\
(5.4)\end{array}$ & $\begin{array}{l}6.8-66.7 \\
(30.5)\end{array}$ \\
\hline $\begin{array}{l}\text { Kavala Gulf } \\
\text { (Stamatis et al., 2019) }\end{array}$ & na & $\begin{array}{l}23.16- \\
185.28 \\
(80.79)\end{array}$ & $\begin{array}{l}0.78-154.0 \\
(25.14)\end{array}$ & $\begin{array}{l}0.84- \\
50.00 \\
(22.32)\end{array}$ & $\begin{array}{l}18.12- \\
203.28 \\
(52.79)\end{array}$ & $\begin{array}{l}48.15- \\
1024.70 \\
(139.78)\end{array}$ \\
\hline $\begin{array}{l}\text { Thessaloniki Bay, Greece } \\
\text { (Christophoridis et al., 2019) }\end{array}$ & na & $\begin{array}{l}65.5-173.5 \\
(121.9)\end{array}$ & $\begin{array}{l}21.3-180.1 \\
(54.4)\end{array}$ & $\begin{array}{l}41.8-171.3 \\
(79.8)\end{array}$ & $\begin{array}{l}29.4-195.4 \\
(62.4)\end{array}$ & $\begin{array}{l}48.6-538.3 \\
(144.6)\end{array}$ \\
\hline $\begin{array}{l}\text { Saronikos Gulf } \\
\text { (Karageorgis et al., 2020) }\end{array}$ & $\begin{array}{l}2-179 \\
(19)\end{array}$ & $\begin{array}{l}19-544 \\
(152)\end{array}$ & $\begin{array}{l}7-365 \\
(52)\end{array}$ & $\begin{array}{l}9-392 \\
(77)\end{array}$ & $\begin{array}{l}5-374 \\
(69)\end{array}$ & $\begin{array}{l}15-982 \\
(169)\end{array}$ \\
\hline $\begin{array}{l}\text { Northern Cysprus } \\
\text { (Abbasi and Mirekhtiary, } \\
\text { 2020) }\end{array}$ & na & $\begin{array}{l}15-93 \\
\text { (na) }\end{array}$ & $\begin{array}{l}11-49 \\
\text { (na) }\end{array}$ & $\begin{array}{l}11-37 \\
\text { (na) }\end{array}$ & $\begin{array}{l}11-22 \\
\text { (na) }\end{array}$ & $\begin{array}{l}26-72 \\
\text { (na) }\end{array}$ \\
\hline $\begin{array}{l}\text { Gulf of Tunis } \\
\text { (Ben Amor et al., 2019) }\end{array}$ & na & $\begin{array}{l}15-55 \\
\text { (na) }\end{array}$ & $\begin{array}{l}1.5-19 \\
\text { (na) }\end{array}$ & $\begin{array}{l}14-51 \\
\text { (na) }\end{array}$ & $\begin{array}{l}16-107 \\
\text { (na) }\end{array}$ & $\begin{array}{l}27-450 \\
\text { (na) }\end{array}$ \\
\hline $\begin{array}{l}\text { Boka Kotorska Bay } \\
\text { (Radomiroviç et al., 2021) }\end{array}$ & $\begin{array}{l}11.1- \\
90.8 \\
(23.2)\end{array}$ & $\begin{array}{l}\text { 65-1652 } \\
(295)\end{array}$ & $\begin{array}{l}18.2-1296 \\
(170)\end{array}$ & $\begin{array}{l}30-389 \\
(177)\end{array}$ & $\begin{array}{l}16.5-351 \\
(74.6)\end{array}$ & $\begin{array}{l}66.6-830 \\
(249)\end{array}$ \\
\hline $\begin{array}{l}\text { Güllük Bay } \\
\text { (Balkıs et al., 2020) }\end{array}$ & na & $\begin{array}{l}0.1-46 \\
\text { (na) }\end{array}$ & $\begin{array}{l}1-59 \\
\text { (na) }\end{array}$ & na & $\begin{array}{l}0.1-209 \\
\text { (na) }\end{array}$ & $\begin{array}{l}10-259 \\
\text { (na) }\end{array}$ \\
\hline
\end{tabular}

\section{Figures}




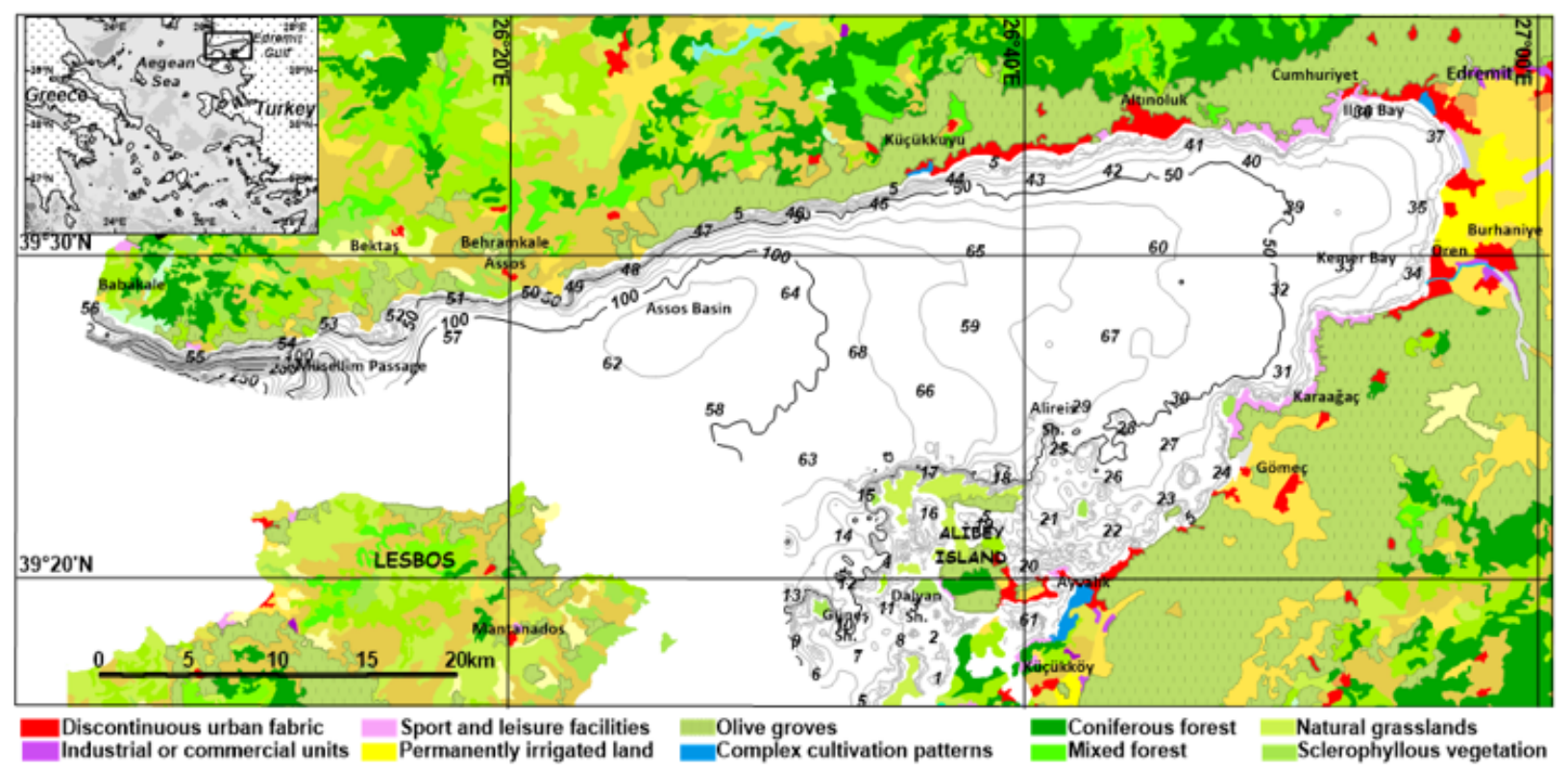

\section{Figure 1}

Land use and bathymetric map of the Edremit Gulf with surface sediment sampling station network.
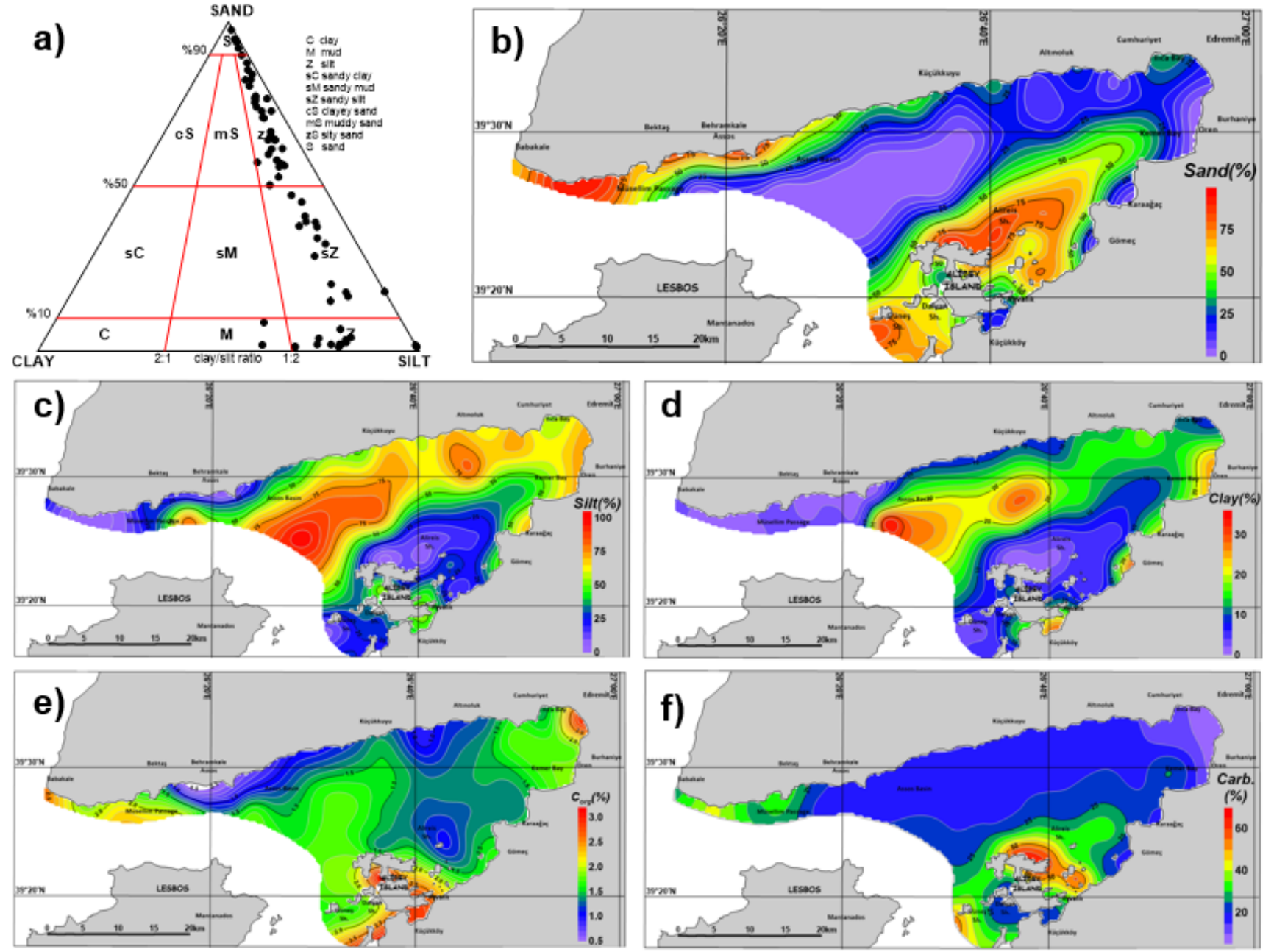

Figure 2 
Sediment classification according to Folk (1974) triangle diagram (a) and areal distribution of sand (b), silt (c), clay (d), organic carbon (e) and carbonate contents (f).
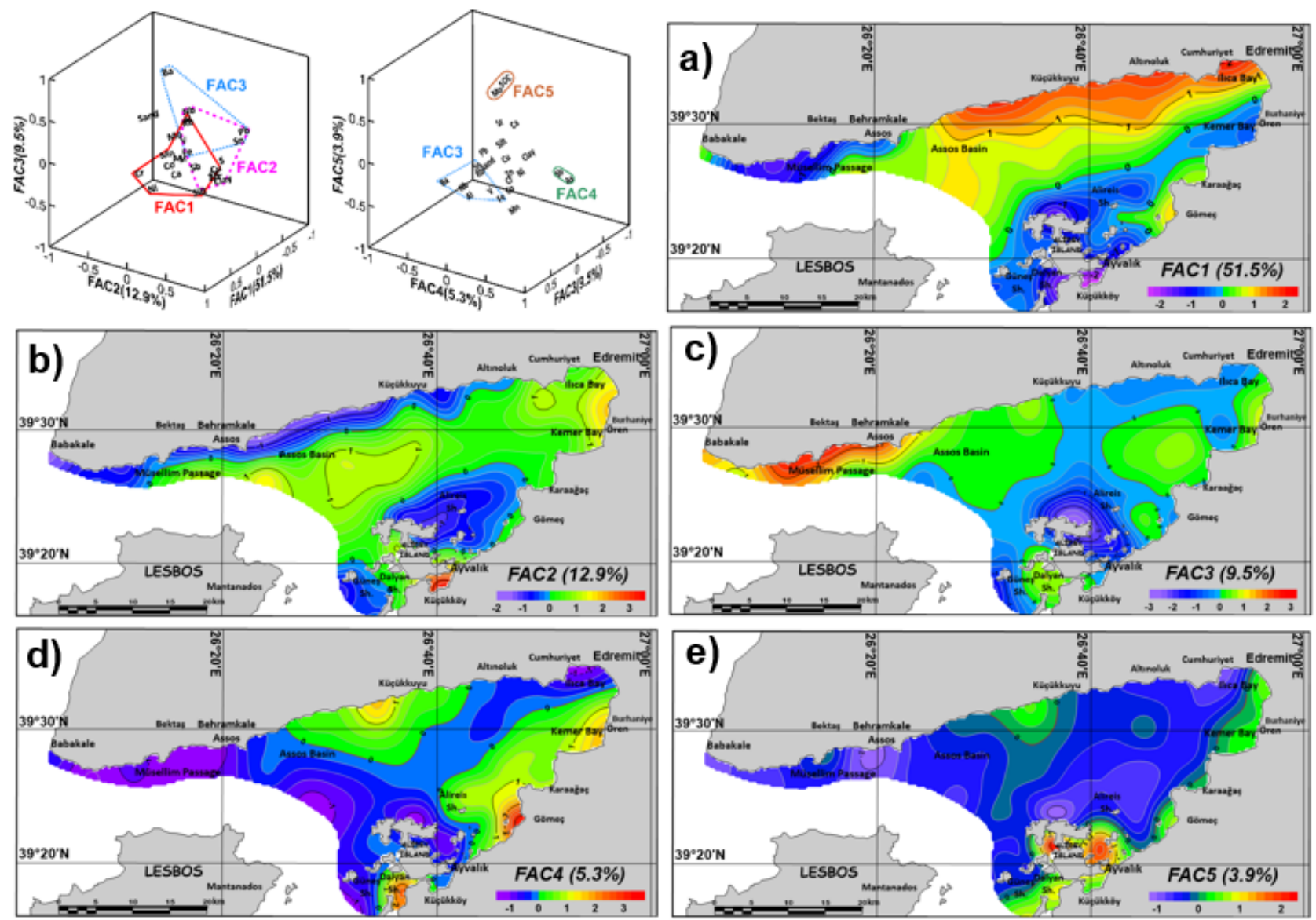

\section{Figure 3}

Spatial distribution of the 5 Factors obtained from Principal Component Analysis; (a)F1: Mining, (b)F2: Marine Traffic, (c)F3: Terrigenous, Lithogenic, (d)F4: wwtp/geothermal, (e)F5: OM sulfurization factors. 

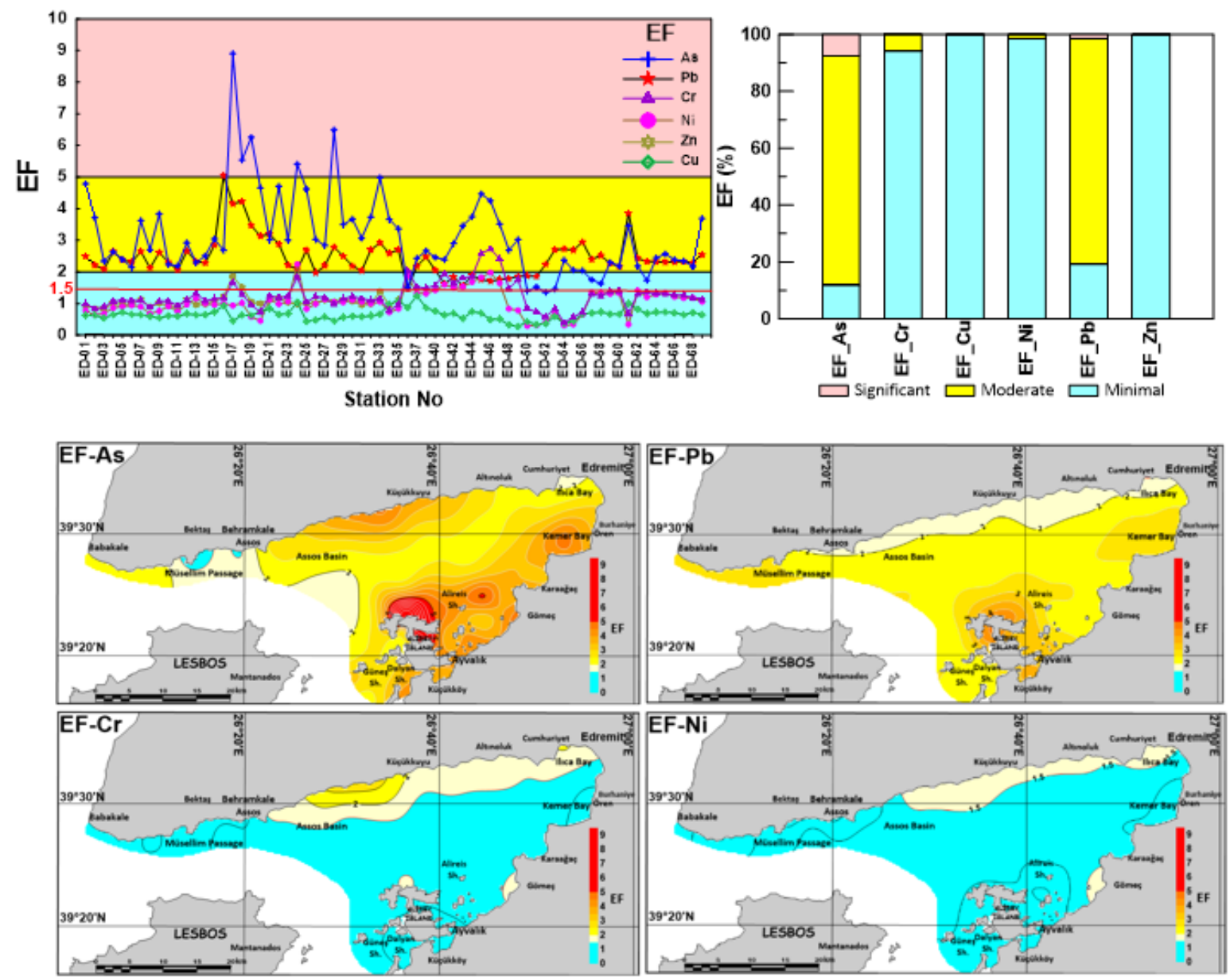

\section{Figure 4}

Stationary (top left) and elementary (top right) distribution of EF values. Areal distribution of EF values for $\mathrm{As}, \mathrm{Pb}, \mathrm{Cr}$ and $\mathrm{Ni}$ are shown in below. 

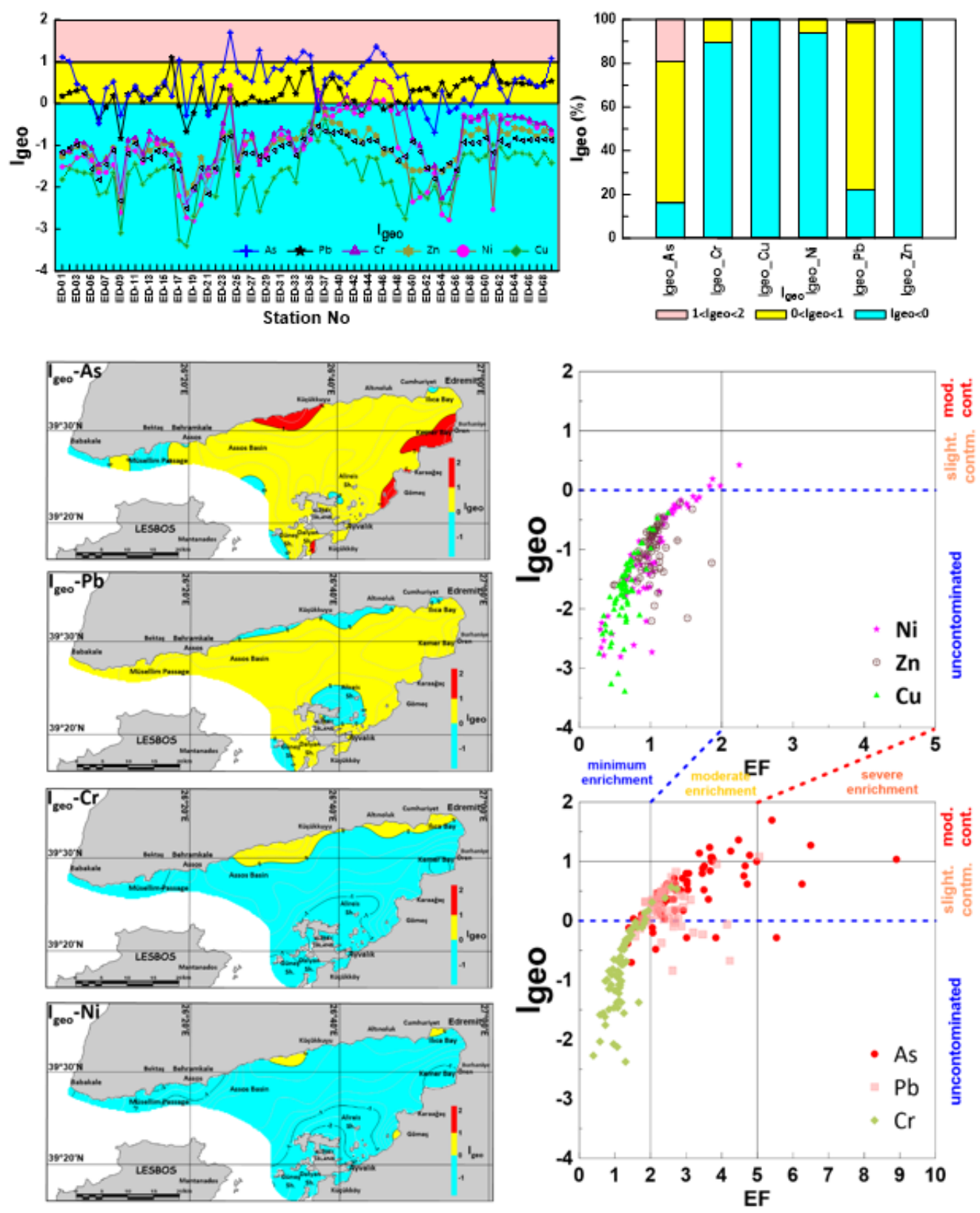

\section{Figure 5}

Stationary (top left) and elementary (top-right) distribution of Igeo values. Areal distribution of Igeo values for $\mathrm{As}, \mathrm{Pb}, \mathrm{Cr}$ and $\mathrm{Ni}$ are shown in below(left). Igeo $<0$ Uncontaminated; 0 

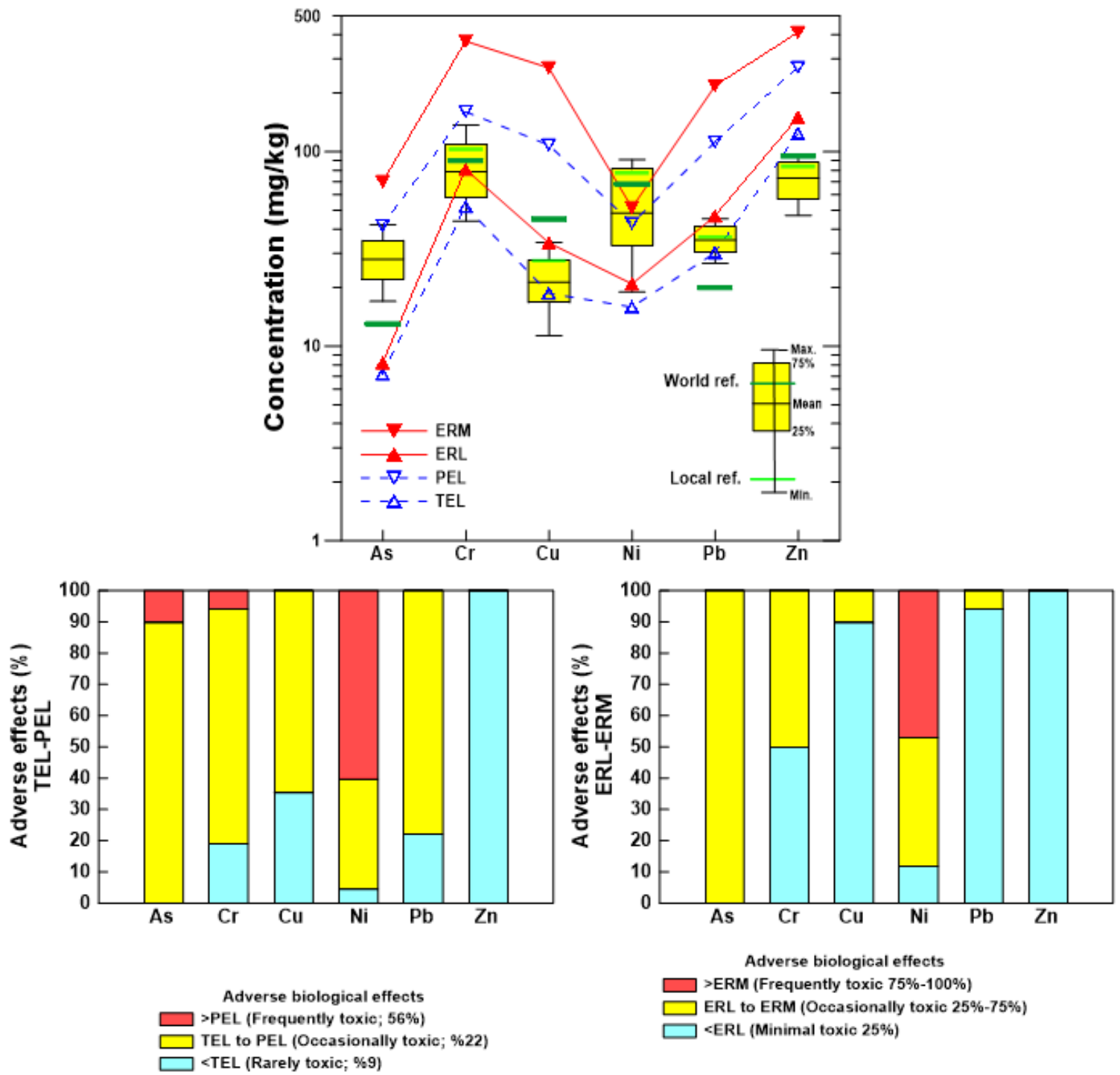

Figure 6

Box and whisker plots for heavy metal concentrations in the surface sediments and SQGs (top), percentage of samples each quideline TEL-PEL (lower left) and ERL-ERM (lower right). 

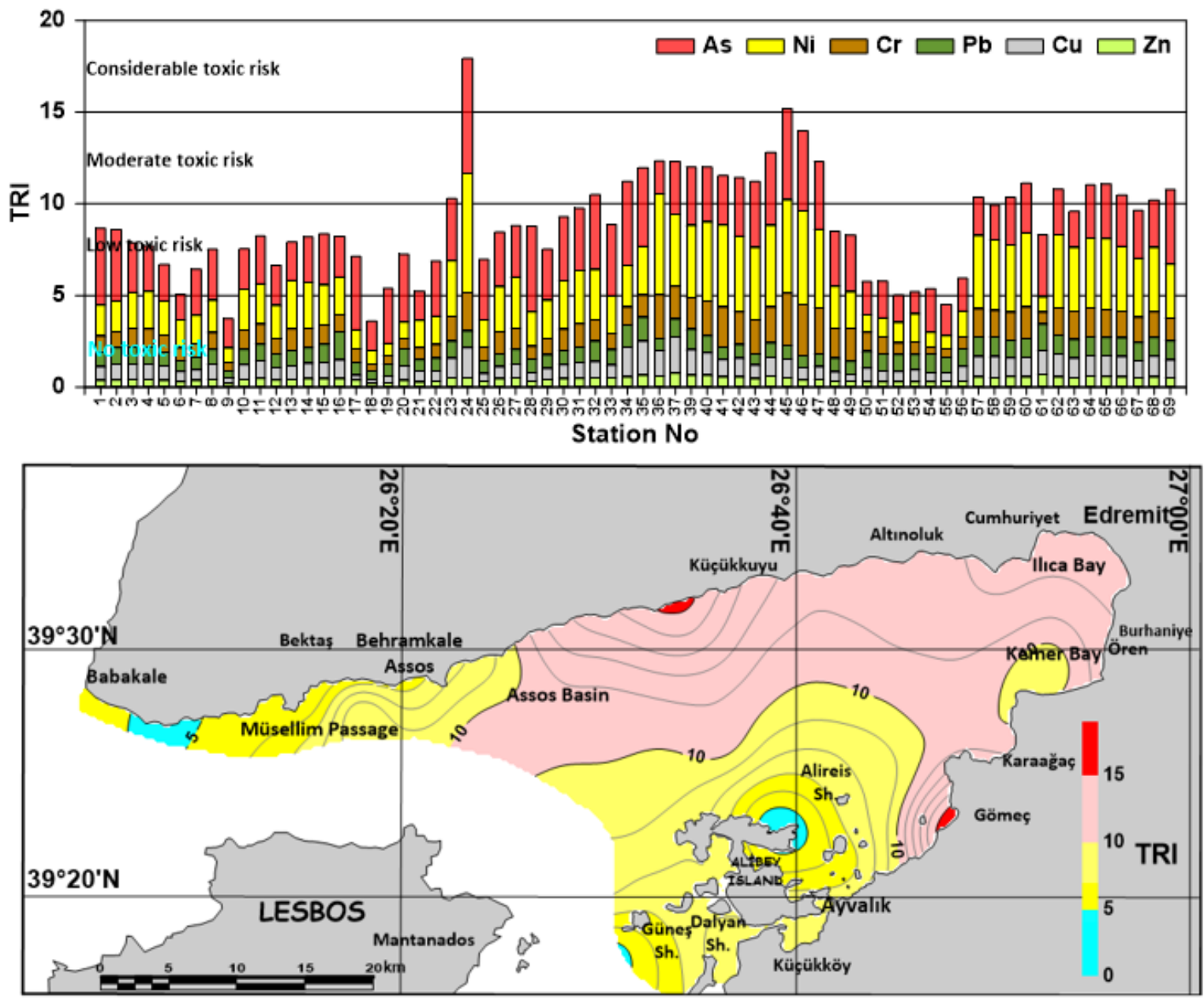

Figure 7

Stationary(top) and Areal distribution(below) of the Toxic Risk Index (TRI).

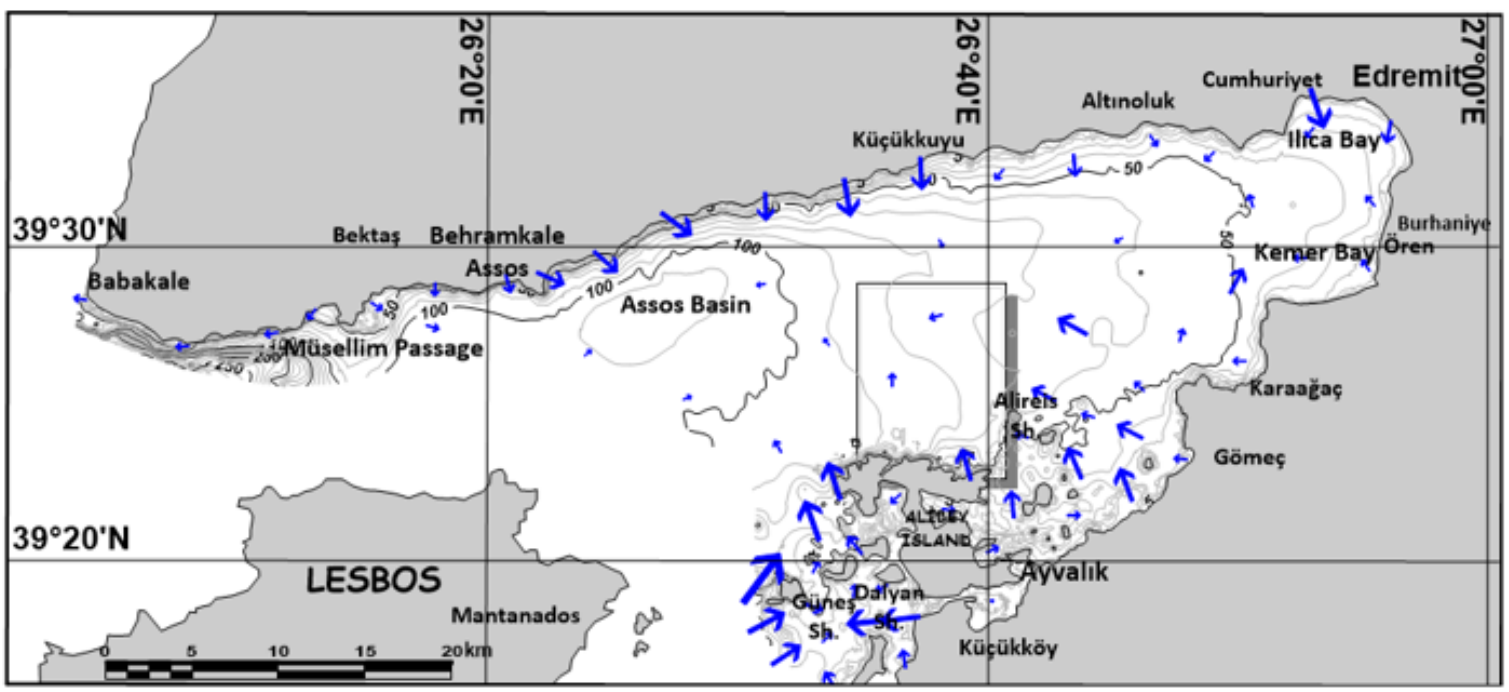

Figure 8

Map showing net sediment transport pattern derived from GSTA model. 


\section{Supplementary Files}

This is a list of supplementary files associated with this preprint. Click to download.

- Attachment.docx 